\title{
Complicidad, responsabilidad penal de directivos empresariales y violaciones de Derechos Humanos cometidas por grupos armados ilegales: lecciones del Derecho Penal Internacional para Colombia*
}

\author{
Complicity, Criminal Liability of Business Leaders and Human Rights Violations Perpetrated by Illegal Armed Groups: \\ Lessons from the International Criminal Law to Colombia
}

Gustavo Emilio Cote-Barco ${ }^{\text {a }}$

Pontificia Universidad Javeriana, Colombia

gcote@javeriana.edu.co

ORCID: http://orcid.org/0000-0002-1060-1622
DOI: https://doi.org/10.11144/Javeriana.vj138.crpd Redalyc: http://www.redalyc.org/articulo.oa?id=82559799005

Fecha de recepción: 30 Julio 2018 Fecha de aprobación: 30 Septiembre 2018

Fecha de publicación: 30 Mayo 2019

\section{Resumen:}

El presente artículo de reflexión plantea algunas consideraciones sobre la imputación de responsabilidad penal a empresarios con base en crímenes cometidos por grupos armados. A partir de allí, se pretende establecer cuándo la Jurisdicción Especial para la Paz, JEP, puede juzgar líderes empresariales, dado que en el Acuerdo de Paz firmado por el Gobierno colombiano y el grupo guerrillero FARC-EP se previó como criterio para definir si la JEP es competente frente a civiles, de una manera algo vaga, la "participación determinante" de estos en la perpetración de crímenes graves. Sobre la base de algunas decisiones judiciales que han sido relevantes en el derecho penal internacional, el artículo sostiene que en este tipo de casos la complicidad ofrece un marco de referencia apropiado para la atribución de responsabilidad. Además, propone diferenciar entre la contribución de la persona jurídica al grupo u organización ilegal y la contribución del empresario dentro de la persona jurídica, con el fin de separar la discusión sobre la competencia de la pregunta por el grado de responsabilidad penal individual.

Palabras clave: Empresas, crímenes internacionales, complicidad, omisión, Colombia, Jurisdicción Especial para la Paz.

\section{Abstract:}

This work discusses some criteria for attributing criminal liability to business leaders for international crimes perpetrated in Colombia by illegal armed groups. Based on it, an attempt is made to stablish when the Special Jurisdiction for Peace (JEP) can judge businessmen, since the Peace Agreement signed by the Colombian Government and the guerrilla group FARC-EP refers, somehow vaguely, to the "determining participation" of civilians in the crimes, as a standard to decide this point. Taking into consideration some relevant decisions for the development of the international criminal law, this article argues that the concept of complicity offers an appropriate framework for imputation in those cases. With the aim to separate the issue of jurisdiction from the question on the degree of individual criminal liability, it also proposes to distinguish between the contribution of a company to an armed group and the contribution of a person inside a company to the action of that company.

Keywords: Corporations, international crimes, aiding and abetting, omission, Colombia, Special Jurisdiction for Peace.

\section{Introducción}

El presente trabajo discute la responsabilidad penal de directivos empresariales por violaciones de derechos humanos $(\mathrm{DDHH})$ o infracciones graves al derecho internacional humanitario (DIH) cometidas por grupos armados, con los cuales las empresas, como personas jurídicas, han tenido algún tipo de interacción, contribuyendo así a la consumación de los crímenes cometidos por aquellos. Se debe aclarar que aquí no se aborda el problema de la posible responsabilidad penal de las personas jurídicas por la comisión de crímenes internacionales, lo cual aún no se ha aceptado ni en Colombia ni en el ámbito internacional y constituye

Notas de autor: 
un debate distinto ${ }^{1}$; se trata más bien de identificar criterios mínimos que puedan orientar el análisis de la imputación de responsabilidad penal individual, por ejemplo, en casos de miembros de juntas directivas, gerentes, administradores o, incluso, accionistas mayoritarios ${ }^{2}$. Como punto de partida se asume que la dificultad propia de estos casos radica en la distancia física, estructural y/o causal que existe entre estas personas y los perpetradores materiales de los crímenes (y, por lo tanto, frente al resultado) ${ }^{3}$, lo cual, valga decirlo, no necesariamente equivale a que normativamente no haya ningún vínculo entre ellos ${ }^{4}$. Precisamente esta circunstancia se debe tener en cuenta al fundamentar la responsabilidad penal e identificar formas de imputación que permitan, por un lado, racionalizar el ejercicio del poder punitivo y, por otro, responder adecuadamente desde el punto de vista político-criminal ante este fenómeno.

Como se explicará más adelante, este constituye un tema fundamental en el contexto de la Jurisdicción Especial para la Paz (JEP), creada recientemente en Colombia como resultado del acuerdo de paz al que llegaron el Gobierno colombiano y el grupo guerrillero FARC-EP (en adelante, Acuerdo de Paz), debido a que la JEP tendrá que juzgar conductas equivalentes a crímenes internacionales y puede ser competente frente a civiles, según lo dispuesto en el Acuerdo mismo y en algunas de las normas que lo implementan, cuando estos hayan tenido una participación determinante en los crímenes cometidos por los grupos armados entre otros requisitos- Como argumento principal del texto, se sostiene, entonces, que tal como ha sido definida en el ámbito internacional, la figura de la complicidad ofrece un marco de referencia apropiado para la atribución de responsabilidad (incluso en casos de omisión), para lo cual se debe distinguir entre la contribución que hace la persona jurídica al grupo u organización ilegal y la contribución o acción concreta del empresario dentro de la persona jurídica. Asimismo, se propone tomar esta distinción como punto de partida para definir la competencia de la JEP frente a empresarios, de ser el caso interpretando la expresión "participación determinante", bajo el entendido de que la delimitación de la competencia y la pregunta sobre el grado de responsabilidad de quienes respondan ante la JEP son dos aspectos que no se deben confundir.

El texto ha sido dividido en cuatro partes: en primer lugar, se harán algunas precisiones con el fin de contextualizar la discusión en el ámbito colombiano; posteriormente, se reseñarán algunos de los casos internacionales más relevantes para el tema objeto de análisis y a partir de allí, se identificarán los criterios mínimos para la imputación de responsabilidad penal a directivos empresariales; en tercer lugar, tomando como punto de referencia lo dicho con relación al derecho penal internacional (DPI), se plantearán algunas reflexiones sobre la responsabilidad de empresarios por violaciones de DDHH en Colombia, con énfasis en la JEP; y, finalmente, a manera de conclusión, se presentarán algunas consideraciones relacionadas con los retos que, precisamente con ocasión de este tipo de casos, deberán afrontar los órganos que integran esta nueva jurisdicción.

Antes de comenzar se deben hacer dos precisiones adicionales. Por un lado, se debe aclarar que el presente trabajo no pretende entonces realizar un análisis de cada una de las distintas posibilidades que ofrece la teoría del delito para atribuir responsabilidad penal en concreto, por ejemplo, a título de autoría o participación; simplemente se quieren plantear algunas reflexiones sobre la imputación de responsabilidad penal a civiles con base en crímenes cometidos por grupos armados (ilegales), tomando como punto de referencia la forma como casos similares han sido tratados en el DPI y, a partir de allí, identificar algún parámetro que pueda servir como punto de partida en la definición de la competencia de la JEP para el juzgamiento de civiles o, más específicamente, de empresarios. Por otro lado, es importante señalar que la relevancia del DPI como marco de referencia en este contexto se desprende no solamente del ámbito de aplicación material de la JEP, en la medida en que sus órganos son competentes para juzgar conductas que en buena parte equivalen a crímenes internacionales, sino también de los elementos establecidos en el Acuerdo de Paz mismo y en el Acto Legislativo 01 de 2017 como derecho aplicable en este para realizar la calificación jurídica de las conductas, ya que entre ellos se menciona esta área del derecho ${ }^{5}$. 


\section{Contexto de la discusión en Colombia: de la Ley 975 de 2005 a la Jurisdicción Especial para la Paz}

El problema de la responsabilidad penal de líderes o directivos empresariales por violaciones masivas de DDHH e infracciones graves al DIH cometidos por grupos armados ilegales ha adquirido en Colombia una relevancia especial desde que tuvo lugar la desmovilización de grupos paramilitares en 2005 y se implementó la Ley 975 de ese mismo año o Ley de Justicia y Paz (LJP). Esta ley creó un proceso penal especial, con el fin de sancionar a los desmovilizados que tuvieran responsabilidad penal por crímenes graves (equivalentes a crímenes internacionales) ${ }^{6}$ y contribuir (a cambio de la imposición de una pena alternativa más benigna que la prevista por la legislación penal ordinaria aplicable a cada caso) ${ }^{7}$ a la construcción de verdad ${ }^{8}$ y a la reparación de las víctimas ${ }^{9}$. Gracias a las versiones libres que rindieron los paramilitares, no solamente se logró recabar una buena cantidad de información sobre la forma como dichos grupos fueron creados y la manera como operaron y expandieron su dominio territorial, sino también sobre las estrategias que ellos utilizaron para adquirir poder político y económico, al cooperar y sellar alianzas con diversos actores legales ${ }^{10}$. Sin embargo, debido a que el régimen procesal previsto en la LJP únicamente es aplicable a miembros de grupos armados ilegales, esta información no podía generar, en el marco de este proceso penal especial, investigaciones contra civiles, de manera que en cada caso debía hacerse la respectiva "compulsa de copias" ${ }^{11}$. La Fiscalía General de la Nación (FGN) debía entonces adelantar nuevas investigaciones en contra de los civiles implicados en las declaraciones de los paramilitares y aplicar la legislación penal ordinaria. Como resultado, frente a los mismos hechos, se generaron diferentes investigaciones, lo cual no solamente puede producir una visión fragmentada de los casos, de por sí complejos, sino también un mayor desgaste institucional ${ }^{12}$.

En las negociaciones que llevaron a cabo el Gobierno nacional y el grupo guerrillero FARC-EP en La Habana (Cuba), se hizo alusión al tema y se intentó corregir esta situación con miras al nuevo sistema de justicia transicional creado para facilitar la desmovilización de ese grupo rebelde ${ }^{13}$. La versión final del Acuerdo de Paz afirma que este sistema parte de la importancia que tiene el reconocimiento de responsabilidad "por parte de todos quienes participaron de manera directa o indirecta en el conflicto y se vieron involucrados de alguna manera en graves violaciones a los DDHH y graves infracciones al DIH” 14 . Este es precisamente uno de los aspectos que reflejan la pretensión que tiene dicho sistema de ser integral ${ }^{15}$. En consecuencia, en el componente de justicia del sistema o JEP, no solamente pueden ser juzgados los crímenes cometidos por combatientes, guerrilleros o miembros de la Fuerza Pública ${ }^{16}$, sino también las conductas de financiación o colaboración con los grupos paramilitares, o con cualquier actor del conflicto ${ }^{17}$. Es más, según el Acuerdo, la FGN debería remitir a la Sala de Reconocimiento de Verdad y Responsabilidad ${ }^{18}$ las compulsas de copias resultado de los procesos de Justicia y $\mathrm{Paz}^{19}$. De esta manera, las investigaciones que actualmente se adelantan como producto de la desmovilización de grupos paramilitares llevada a cabo en 2005 y que involucran empresarios tendrían que pasar a esta nueva jurisdicción.

La pretensión del Acuerdo de Paz de que se juzgara de alguna manera a todos aquellos que tuvieran responsabilidad penal en la comisión de crímenes graves se vio, sin embargo, limitada por la Corte Constitucional, al declarar inexequible el inciso segundo del artículo transitorio 16 del Título Transitorio de la Constitución Política sobre normas para la terminación del conflicto armado, que preveía la comparecencia de "terceros" antes la JEP ${ }^{20}$. Esta norma fue incluida en el texto constitucional mediante el Acto Legislativo 01 de 2017, el cual dio "vida" jurídica a la JEP en el ordenamiento jurídico colombiano. Para la Corte Constitucional, el inciso segundo del artículo transitorio 16 violaba el principio de juez natural, debido que en él se contemplaba la comparecencia obligatoria de civiles ante órganos judiciales creados ad hoc con 
posterioridad a los hechos cometidos por ellos ${ }^{21}$. Como consecuencia, la competencia de la JEP frente a civiles quedó supeditada al sometimiento voluntario de cada sujeto ${ }^{22}$.

En todo caso, la competencia de la JEP para juzgar civiles no fue prevista desde un principio de manera absoluta. En el Acuerdo de Paz el juzgamiento de civiles por parte de la JEP se condicionó, entre otros requisitos, a que el sujeto en cuestión hubiera tenido una "participación activa o determinante en la comisión de los crímenes” de su competencia ${ }^{23}$. Este criterio había sido incorporado también en el inciso segundo del artículo transitorio 16 del Acto Legislativo 01 de 2017 y la expresión "participación determinante" había sido definida en esta misma disposición como "aquella acción eficaz y decisiva en la realización de los delitos enunciados". El criterio "participación activa o determinante" permitía entonces diferenciar los casos de civiles a ser juzgados en la JEP de aquellos frente a los cuales procederían beneficios como la renuncia a la persecución penal, prevista en la Ley 1820 de 2016 — también denominada Ley de Amnistía o LA— ${ }^{24}$. Sin embargo, al parecer, con la decisión de la Corte Constitucional, la aplicabilidad de este criterio queda en entredicho, pues al declararse inexequible el artículo transitorio 16, aquel desapareció del Acto Legislativo que, como ya se indicó, otorgó fundamento constitucional a los órganos judiciales cuya creación se previó en el Acuerdo.

Así las cosas, sería posible preguntarse: ¿cómo se diferenciará ahora en el contexto de la JEP entre los casos que deben ser juzgados y los que admiten beneficios? ¿O, como consecuencia de lo dicho por la Corte Constitucional, cualquier caso será susceptible de ser juzgado, siempre y cuando medie el consentimiento del civil involucrado? Al respecto, se debe precisar que la existencia de algún criterio para distinguir entre estos dos tipos de casos sigue siendo fundamental para mantener, en lo posible, el espíritu del Acuerdo y sobre todo su coherencia, dado que esta distinción también se hace con relación a los demás actores del conflicto - aunque con relación, por ejemplo, a miembros de las FARC el criterio diferenciador es el tipo de crímenes cometidos- ${ }^{25}$. Además, hay otras disposiciones de implementación del Acuerdo de Paz en las que se sigue haciendo referencia, al menos, a la idea de "participación determinante" de terceros civiles en crímenes cometidos por grupos armados. En este sentido, es posible mencionar el artículo 28 (8) de la LA, el cual se refiere a "la definición de la situación jurídica de aquellos terceros que se presenten voluntariamente a la jurisdicción en los 3 años siguientes de su puesta en marcha [...] cuando no hayan tenido una participación determinante en los delitos más graves y representativos" (cursivas por fuera del texto original) ${ }^{26}$. Por lo tanto, a pesar de la decisión de la Corte Constitucional sobre el artículo transitorio 16, al menos la pregunta sobre el significado de la expresión "participación determinante", especialmente con relación a terceros civiles, sigue siendo relevante.

\section{Responsabilidad penal de directivos empresariales en el derecho penal internacional: de los tribunales penales militares posteriores a la Segunda Guerra Mundial al Tribunal Penal Internacional de Ruanda}

Aunque no hay una gran cantidad de casos, en el ámbito internacional han tenido lugar algunos procesos penales en los que empresarios han sido juzgados por haber participado en la comisión de crímenes internacionales. De este problema se ocuparon especialmente los tribunales instaurados una vez finalizó la Segunda Guerra Mundial por los países aliados y que juzgaron criminales de guerra alemanes. Adicionalmente, hay algunos casos del Tribunal Penal Internacional de Ruanda (TPIR, United Nations International Criminal Tribunal for Rwanda, UNICTR) en los que también fueron juzgados empresarios con ocasión del genocidio del pueblo tutsi ocurrido en ese país africano entre el 7 de abril y el 15 de julio de $1994^{27}$. A continuación, se presentarán algunos de los casos más relevantes, con el fin de identificar criterios mínimos relacionados con la imputación de responsabilidad penal a empresarios, que puedan ser tenidos en cuenta en el contexto colombiano. Estos casos permiten afirmar que en el DPI tanto la responsabilidad penal 
por complicidad como la responsabilidad por omisión con fundamento en la posición de superior jerárquico han sido de especial relevancia.

\section{Tribunales penales militares instaurados con posterioridad a la Segunda Guerra Mundial}

Los procesos a los que se hace referencia se realizaron conforme a la Ley No. 10, expedida el 20 de diciembre de 1945, por el Consejo de Control conformado por los países aliados: Estados Unidos, Reino Unido, Francia y la Unión Soviética (CCL No. 10, por sus siglas en inglés) ${ }^{28}$. Estos procesos tuvieron lugar en las distintas zonas de ocupación en las que fue dividida Alemania al finalizar la Segunda Guerra Mundial. La CCL No. 10 fue expedida con el fin de dar cumplimiento a la Declaración de Moscú del 30 de octubre de $1943^{29}$ y al Acuerdo de Londres, firmado el 8 de agosto de $1945^{30}$. En líneas generales, esta ley reproducía en su artículo II (numeral 1, literales a., b. y c.) los crímenes definidos en el artículo 6 del Estatuto del Tribunal Penal Militar de Núremberg (TPM), ante el cual fueron juzgados los principales criminales de guerra ${ }^{31}$, a saber: crímenes contra la paz, crímenes de guerra y crímenes de lesa humanidad. Además, en el literal d. del artículo II (1) CCL No. 10 se incluyó como un cuarto crimen la pertenencia a un grupo u organización que hubiera sido declarado criminal por el Tribunal Penal Militar de Núremberg conforme al artículo 9 de su Estatuto. La CCL No. 10 autorizaba al comandante de cada zona para establecer el tribunal ante el cual las personas acusadas de cometer estos crímenes debían ser juzgadas —artículo III (2) - , aunque también permitía que en casos de conductas realizadas por ciudadanos alemanes contra alemanes fuera un tribunal alemán el encargado de llevar a cabo el juzgamiento — artículo III (1) (d) - . Pues bien, aquí interesa resaltar tres de los procesos que tuvieron lugar en la zona de ocupación estadounidense: los denominados procesos Flick, Krupp e I. G. Farben. Asimismo, se debe mencionar el proceso llevado a cabo en la zona de ocupación británica conocido como proceso Zyklon $B$.

Entre el 20 de abril y el 22 de diciembre de 1947, se llevó a cabo ante el Tribunal Militar IV con sede en la ciudad de Núremberg el juicio contra Friedrich Flick y otros cinco miembros del grupo empresarial Flick ${ }^{32}$ . En la acusación se formularon cargos por haber sometido a trabajos forzados a prisioneros de guerra y en general a personas recluidas en campos de concentración, despojo de propiedad tanto en Francia como en la Unión Soviética al estar bajo ocupación alemana y "arianización” de la propiedad industrial y minera judía, así como por la pertenencia y apoyo financiero a la SS (Schutzstaffel) ${ }^{33}$. Los acusados Friedrich Flick (trabajo forzado, despojo, colaboración con y financiación de la SS), Otto Steinbrinck (pertenencia y apoyo a la SS) y Bernhard Weiss (trabajos forzados) fueron declarados culpables, mientras que los otros tres acusados (Odilo Burkart, Konrad Kaletsch y Hermann Terberger) fueron absueltos ${ }^{34}$.

De este proceso se deben resaltar tres aspectos. En primer lugar, el Tribunal aclaró que el hecho de que los acusados fueran civiles y no ostentaran ningún cargo oficial no constituía un impedimento para declararlos penalmente responsables con fundamento en el derecho internacional ${ }^{35}$. En este sentido, el Tribunal se refirió a la decisión del TPM de Núremberg, en la cual solo fueron condenados como "major war criminals" agentes estatales, para aclarar que esto no significa que el derecho internacional, al igual que el derecho nacional, no sea vinculante para todos los individuos de un Estado, sin importar su condición ${ }^{36}$. En segundo lugar, se debe resaltar que, no obstante la posición de liderazgo que tenían los acusados en el grupo empresarial Flick, el Tribunal se abstuvo de realizar una imputación general a todos ellos y, por el contrario, en cumplimiento del principio según el cual la responsabilidad penal es individual, analizó en qué medida cada uno de ellos contribuyó a la comisión de los crímenes objeto de la acusación. Así, por ejemplo, Steinbrinck, Burkart, Kaletsch y Terberger fueron absueltos con relación a la participación en el programa de trabajo forzado creado por el Gobierno Nacionalsocialista (primer cargo), dado que ellos no participaron en el diseño de dicho programa ni tenían ningún tipo de control sobre su implementación, ni siquiera en las plantas administradas 
por ellos ${ }^{37}$. De hecho, el Tribunal reconoció que su participación en la ejecución de dicho programa se dio bajo circunstancias de necesidad, ya que estaban bajo la vigilancia permanente tanto de la SS como de oficiales del ejército alemán ${ }^{38}$. En cambio, Flick y Weiss sí fueron encontrados culpables, dado que este último realizó acciones por iniciativa propia, con el conocimiento y aprobación de aquel, orientadas a incrementar el personal y la producción ${ }^{39}$. En tercer lugar, es importante anotar que para el Tribunal la financiación de una organización, sabiendo que esta cometía masivamente acciones que podían ser consideradas como crímenes de guerra y de lesa humanidad, permitiría atribuir al menos responsabilidad penal accesoria (es decir, a título de complicidad) por dichos crímenes ${ }^{40}$.

El proceso contra Alfried Felix Alwyn Krupp von Boblen und Halbach y otras once personas, quienes ocuparon diferentes posiciones directivas en el grupo empresarial Krupp, tuvo lugar ante el Tribunal Militar III, también ubicado en Núremberg, entre el 17 de noviembre de 1947 y el 30 de junio de $1948^{41}$. Alfried Krupp y otros ocho de los acusados pertenecieron en diferentes momentos a la "junta directiva" (Vorstand) de ese grupo empresarial, aunque a partir de diciembre de 1943 Alfried Krupp adquirió la condición de único dueño y director principal, asistido por un Direktorium compuesto por los miembros de la antigua junta directiva ${ }^{42}$. Con relación a todos los acusados, con excepción de Heinrich Lehmann y Hans Albert Gustav Kupke, se presentaron cargos por despojo de propiedad en varios países ocupados por Alemania (segundo cargo); además, todos ellos fueron acusados por crímenes de guerra y de lesa humanidad con base en su participación en el programa de trabajo forzado implementado en este país durante el Gobierno Nacionalsocialista (tercer cargo) ${ }^{43}$. De ellos, solamente fue absuelto Karl Heinrich Pfirsch ${ }^{44}$.

De este proceso, al igual que en Flick, resalta el reconocimiento del carácter individual de la culpabilidad ${ }^{45}$ . En este sentido, el Tribunal afirmó que el solo hecho de haber ostentado una posición directiva en el grupo empresarial no constituía fundamento suficiente para declarar que los acusados eran penalmente responsables 46 . Para esto, citando un famoso texto en el ámbito estadounidense que recopila casos sobre corporaciones 47 , el Tribunal aceptó como regla que, para sancionar a los directivos empresariales por acciones delictivas realizadas en el curso de los negocios de la empresa, estas debían haber sido cometidas directamente por aquellos o bajo su dirección o autorización, suponiendo que los directivos tenían conocimiento al respecto o intención criminal ${ }^{48}$. El tipo de contribución a los hechos imputados fue finalmente tenido en cuenta por el Tribunal para determinar las sanciones a imponer ${ }^{49}$.

Ante el Tribunal Militar VI, entre el 14 de agosto de 1947 y el 29 de julio de 1948, fueron juzgados, también en Núremberg, Carl Krauch y otros 22 directivos del grupo empresarial I. G. Farben ${ }^{50}$. Al igual que en los procesos Flick y Krupp, aquí se imputaron, entre otros ${ }^{51}$, cargos por crímenes de guerra y de lesa humanidad con base en el despojo perpetrado en territorios ocupados por Alemania (por ejemplo, Polonia, Noruega y Francia) y trabajos forzados de prisioneros de guerra (cargos dos y tres) ${ }^{52}$. Pero, además, también como parte de estas dos categorías de crímenes, se levantaron cargos por haber proveído el gas a base de cianuro Zyklon $\mathrm{B}$ a varios campos de concentración en los que fue utilizado con fines de exterminio ${ }^{53}$, así como drogas y medicamentos con los que se realizaron experimentos no consentidos en los prisioneros ${ }^{54}$. Este Tribunal, como también sucedió en los otros dos procesos ya reseñados, reafirmó el principio de culpabilidad individual al precisar que para que haya responsabilidad penal, los acusados debían haber participado en la realización de un acto ilegal o debieron haberlo aprobado o autorizado, siendo conscientes de su carácter criminal ${ }^{55}$. Sin embargo, el Tribunal aclaró que, aunque el hecho de haber pertenecido, por ejemplo, a la junta directiva de una empresa o grupo empresarial no era suficiente, la estructura muchas veces compleja de este tipo de organizaciones no representaba un obstáculo para fundamentar la responsabilidad penal ${ }^{56}$. En consecuencia, para el Tribunal era posible declarar penalmente responsables a los directivos de $I$. G. Farben, así estos no hubieran realizado siempre directamente o por sí mismos los actos concretos de despojo y así estos actos hubieran tenido lugar en desarrollo de la política de explotación de los territorios ocupados implementada 
por el Gobierno alemán durante la guerra ${ }^{57}$. El hecho de que varios de estos actos hubieran consistido en "negociaciones" con apariencia de legalidad tampoco constituía una razón para eximirlos de responsabilidad, puesto que los dueños originales de los bienes participaban en estas transacciones bajo presión ${ }^{58}$.

En todo caso, este Tribunal también realizó el análisis de responsabilidad de manera individual. Así, por ejemplo, Carl Krauch fue absuelto con relación a hechos ocurridos en Noruega, puesto que, a pesar de haber participado en algunas negociaciones como experto-técnico, el rol que cumplió no fue considerado lo suficientemente relevante ${ }^{59}$, a diferencia de lo ocurrido con Hermann Schmitz, otro de los acusados, quien fue declarado culpable por hechos ocurridos tanto en Francia como en Noruega, en donde, con su autorización, se realizaron varias operaciones comerciales que condujeron al despojo ${ }^{60}$. Otro ejemplo relevante es el caso de Fritz Gajewski, ya que, según el Tribunal, en el juicio no se logró probar que éste hubiera llevado a cabo alguna acción criminal o que la hubiera ordenado o autorizado, así como tampoco que hubiera obrado con conocimiento de los elementos que hacían criminales los hechos objeto de discusión ${ }^{61}$. Este último caso demuestra la relevancia del aspecto subjetivo de la imputación cuando el acusado ha estado alejado desde el punto de vista objetivo (causal) de la realización de los hechos, así como la dificultad que implica probar ese elemento ${ }^{62}$. Precisamente, esto se puede observar también respecto a los cargos relacionados con el Zyklon B y los medicamentos que se proporcionaron a la SS. El gas venenoso era comercializado por Degesch, una firma filial del grupo I. G. Farben ${ }^{63}$ y era empleado para el exterminio de insectos. Pues bien, el Tribunal concluyó que ni el volumen de la producción ni el hecho de que grandes envíos de este insecticida estuvieran destinados a los campos de concentración permitían inferir que los acusados, a pesar de estar al tanto de estas circunstancias, fueran conscientes del propósito criminal con que dicha sustancia era utilizada ${ }^{64}$. Lo mismo ocurrió con el envío de medicamentos: saber que eran enviados a los campos de concentración y que eran aplicados a los prisioneros no equivalía a conocer la intención criminal — por ejemplo— de los médicos que deliberadamente infectaban personas con tifus para probar posteriormente en ellas las vacunas enviadas por Farben ${ }^{65}$.

En la zona de ocupación británica, más concretamente en la ciudad de Hamburgo, tuvo lugar entre el 1 y el 8 de marzo de 1946, también ante un tribunal militar, el Zyklon B-Case. En este proceso, fueron juzgadas tres personas: Bruno Tesch, Karl Weinbacher y Joachim Drosihn. El primero de ellos era dueño y director de la firma Tesch \& Stabenow GmbH; el segundo se desempeñó como Procurist o segundo al mando en esta empresa y el tercero era el técnico principal de la firma y experto en gases ${ }^{66}$. Los tres fueron acusados de haber participado en la comisión de crímenes de guerra al suministrar gas Zyklon B, el cual, como ya se mencionó, fue utilizado en varios campos de concentración por la SS para llevar a cabo el exterminio de prisioneros ${ }^{67}$. Tanto Tesch como Weinbacher fueron condenados a muerte, mientras que Drosibn fue absuelto ${ }^{68}$. El Tribunal rechazó el argumento presentado por la defensa de Tesch y Weinbacher, según el cual estos actuaron por temor a las represalias que pudiera tomar la SS si se hubieran negado y que, de todas maneras, de haberlo hecho, la SS hubiera logrado su objetivo por otros medios ${ }^{69}$. Adicionalmente, el Tribunal aclara, de forma similar a como lo hizo el Tribunal Militar IV de la zona de ocupación estadounidense en Flick, que no solo los combatientes pueden ser responsables por crímenes de guerra y que incluso particulares pueden serlo si llevan a cabo actos que contribuyan a su perpetración ${ }^{70}$. En este caso, la contribución se llevó a cabo mediante transacciones comerciales realizadas precisamente por civiles ${ }^{71}$. Respecto a Drosibn, el Tribunal sostuvo que no podía ser declarado penalmente responsable, así hubiera sabido del uso que se le estaba dando al gas venenoso, debido a la posición de subordinación que tenía en la empresa y a que, por esto mismo, no tenía capacidad de influir en o de evitar el envío del gas, por ejemplo, al campo de concentración de Auschwitz ${ }^{72}$. 


\section{Tribunal Penal Internacional de Ruanda}

Además de los procesos penales reseñados en el apartado anterior, para el tema objeto de este trabajo también son relevantes algunos casos juzgados por el TPIR [UNICTR]. De acuerdo con el artículo 1 de su Estatuto, la competencia de este Tribunal se extendía sobre todas las personas (naturales) responsables de violaciones graves al DIH cometidas en territorio ruandés, o por ciudadanos de dicho país perpetradas en países vecinos, entre el 1 de enero y el 31 de diciembre de $1994^{73}$. Aunque, más exactamente, los artículos 2, 3 y 4 del Estatuto limitaban la competencia material, respectivamente, al crimen de genocidio, a los crímenes de lesa humanidad y a las violaciones del artículo 3 común a los convenios de Ginebra y al Protocolo Adicional II. Pues bien, tal como ocurrió con posterioridad a la Segunda Guerra Mundial, en este contexto, los responsables de crímenes internacionales tampoco fueron únicamente militares o combatientes en sentido estricto. Por esta razón, también aquí se discutió sobre la responsabilidad penal de empresarios, aunque su participación en los crímenes fue más directa en este caso, lo cual facilitó acudir simultáneamente a distintas formas de imputación. En este sentido, es posible mencionar en particular dos decisiones de la Cámara de Juzgamiento I de este Tribunal: la sentencia proferida en contra de Alfred Musema el 27 de enero de 2000 y la sentencia dictada en contra de Ferdinand Nabimana, Jean Bosco-Barayagwiza y Hassan Ngeze el 3 de diciembre de 2000.

Musema se desempeñó desde 1984 y durante los hechos que tuvieron lugar en 1994 como director de la Gisovu Tea Factory, una de las fábricas de té más importantes de Ruanda ${ }^{74}$. Con base en su participación directa en varios ataques a gran escala en contra de la población tutsi ${ }^{75}$, en los que también estuvieron involucrados empleados de esta fábrica, le fueron imputados cargos por genocidio, crímenes de lesa humanidad y violaciones al artículo 3 común y al Protocolo II. Respecto a la forma de responsabilidad penal, la Cámara de Juzgamiento I afirmó en varias ocasiones que Musema no solo era penalmente responsable de acuerdo con el artículo 6 (1) del Estatuto del TPIR, el cual regula tanto la participación directa como la indirecta en la perpetración de los crímenes ${ }^{76}$, sino también con el artículo 6 (3), que hace referencia a la responsabilidad del superior jerárquico por los crímenes cometidos por sus subordinados ${ }^{77}$. Para esto, la Cámara se remitió al artículo 86 del Protocolo Adicional I de los Convenios de Ginebra e hizo alusión a la sentencia de la Cámara de Juzgamiento del TPIY en el caso Čelebići, con el fin de afirmar que esta forma de responsabilidad era aplicable tanto a superiores militares como a civiles ${ }^{78}$. Para la Cámara de Juzgamiento I del TPIR el elemento decisivo que permite fundamentar esta forma de responsabilidad es el control efectivo, bien sea de jure o de facto, sobre las personas que cometen materialmente los crímenes ${ }^{79}$. Dicho control puede derivarse de la presión psicológica que ejerce el superior y puede darse incluso sobre individuos que formalmente, por ejemplo de acuerdo con la estructura de la empresa, no son sus subordinados ${ }^{80}$. Para la Cámara, Musema tenía control efectivo sobre sus empleados y, a pesar de esto, no hizo nada para evitar que cometieran los crímenes por los cuales fue condenado, sabiendo que esos crímenes se iban a cometer ${ }^{81}$.

Respecto a la segunda decisión arriba mencionada, se debe llamar la atención sobre las consideraciones que realiza la Cámara de Juzgamiento con relación a Ferdinand Nahimana y a Jean Bosco-Barayagwiza ${ }^{82}$. Nabimana fue fundador de la compañía Radio Télévision Libre des Mille Collines, S.A. (RTLM) y miembro del partido Mouvement Révolutionnaire National pour le Devéloppement (MRND) ${ }^{83}$. Fue acusado, entre otros, con base en el artículo 6 (3) del Estatuto del TPIR, por instigación pública a cometer genocidio y crímenes de lesa humanidad, específicamente por el crimen de persecución ${ }^{84}$. Jean Bosco-Barayagwiza fue miembro fundador del partido Coalition pour la Defense de la République (CDR), miembro del comité d'initiative que organizó la fundación de RTLM y director de la oficina de asuntos políticos del Ministerio de Relaciones Exteriores ${ }^{85}$. Igualmente, fue acusado, entre otros, con base en el artículo 6 (3) del Estatuto del TPIR por instigación al genocidio, genocidio, crímenes de lesa humanidad y violaciones al artículo 3 común 
${ }^{86}$. La Cámara de Juzgamiento encontró tanto a Nahimana como a Barayagwiza penalmente responsables por las transmisiones que se realizaron por RTLM y que incitaron a la comisión del genocidio contra los tutsi, debido al rol que ellos cumplieron en la creación de esta cadena y al control que ejercían sobre ella ${ }^{87}$. Sin embargo, de manera algo confusa, al final la responsabilidad penal de Nabimana tuvo como fundamento únicamente el artículo 6 (1) del Estatuto del TPIR y solo la responsabilidad de Barayagwiza se basó en el artículo 6 (3), aunque también respecto a este último se invocó el artículo 6 (1) ${ }^{88}$. En todo caso, el Tribunal afirma que, si bien estos dos acusados no decidían sobre el contenido específico de cada una de las transmisiones, estas reflejaban una línea editorial por la que ellos eran responsables ${ }^{89}$. Adicionalmente, a pesar de tener suficiente control (incluso de facto) y de saber lo que estaba ocurriendo en RTLM, ninguno de ellos hizo nada por detener la transmisión de los mensajes de odio ${ }^{90}$.

Se debe mencionar que la Cámara de Apelaciones reversó la decisión de la Cámara de Juzgamiento respecto a la declaración de responsabilidad tanto de Nabimana como de Barayagwiza por instigación al genocidio a través de RTLM. Para la Cámara de Apelaciones, la creación como tal de esta cadena no era razón suficiente para fundamentar la responsabilidad penal ${ }^{91}$. Con relación a Nabimana, la Sala consideró que no se logró probar que este hubiera intervenido activamente en la determinación de los contenidos de RTLM ${ }^{92}$, mientras que con relación a Barayagwiza la Sala de Apelaciones afirmó que este solo tuvo posición de superior en RTLM antes del 6 de abril de 1994 y que los actos de instigación al genocidio se dieron con posterioridad a esa fecha, momento a partir del cual el acusado no tuvo control efectivo ${ }^{93}$. De hecho, la Sala cuestionó la referencia simultánea a varias formas de responsabilidad, concretamente a la responsabilidad directa con base en el artículo 6 (1) y a la responsabilidad del superior jerárquico conforme al artículo 6 (3) del Estatuto y aclaró que si estas dos formas de imputación efectivamente eran concurrentes, se debía dar prioridad a la primera de ellas como base de la responsabilidad, mientras que la segunda podía ser tenida en cuenta como circunstancia de agravación ${ }^{94}$. De cualquier manera, la Sala de Apelaciones no negó que el artículo 6 (3) del Estatuto del TPIR también fuera aplicable a civiles; las razones para no confirmar la decisión de la Sala de Juzgamiento en los puntos aquí señalados fueron más bien probatorias. Esta Sala resaltó, como regla general, que la responsabilidad del superior por los hechos de los subordinados no solo surge cuando estos han cometido directamente los crímenes, sino también cuando los han planeado, instigado o cuando han contribuido de cualquier otra manera a su perpetración, siempre y cuando sea posible afirmar que el superior tenía control efectivo sobre ellos ${ }^{95}$.

\section{Criterios (mínimos para la imputación de responsabilidad penal a directivos empresariales en casos de comisión de crímenes internacionales: entre la complicidad y la responsabilidad penal por omisión}

Los procesos penales que aquí se han reseñado hacen referencia a tres tipos de casos, todos ellos relevantes en el contexto colombiano: (i) colaboración o participación en la comisión de crímenes indeterminados mediante la financiación a organizaciones consideradas criminales, (ii) colaboración o participación en la comisión de crímenes indeterminados mediante la provisión de bienes o servicios a organizaciones de esta clase y (iii) comisión directa de crímenes concretos, incluso mediante actos con apariencia de legalidad ${ }^{96}$. Estos procesos permiten identificar, además, algunos criterios mínimos que pueden orientar la imputación de responsabilidad penal a empresarios por casos de comisión de crímenes internacionales. 


\section{Responsabilidad penal de directivos empresariales a título de complicidad}

Como punto de partida se debe resaltar la importancia del principio de culpabilidad y de la necesidad que se desprende de este de evitar sanciones grupales que no encuentren fundamento en las acciones que cada persona voluntariamente ha realizado ${ }^{97}$. Esto puede parecer una obviedad. Sin embargo, teniendo en cuenta la naturaleza colectiva de los crímenes internacionales ${ }^{98}$, no solamente desde el punto de vista de la cantidad de víctimas que estos generan, sino también de la forma como se cometen ${ }^{99}$, la identificación de contribuciones individuales en estos contextos no siempre es tarea fácil ${ }^{100}$. Como aquí se ha visto, el solo hecho de pertenecer a una organización (legal) que, en cuanto persona jurídica, ha participado en la comisión de crímenes internacionales, no es suficiente como fundamento de la responsabilidad penal. Para esto se deben cumplir algunos requisitos, tanto objetivos como subjetivos, los cuales, al menos cuando se trata de los casos (i) y (ii) mencionados en el párrafo anterior, ubican la discusión sobre la forma de responsabilidad (en principio) en el ámbito de la responsabilidad penal accesoria o complicidad ${ }^{101}$.

Desde el punto de vista objetivo, en términos generales se requiere entonces que el individuo cuya responsabilidad se esté analizando haya facilitado la comisión de los crímenes. Sin embargo, no cualquier tipo de aporte es suficiente; se necesita que el aporte haya tenido cierta relevancia ${ }^{102}$. Pero, justamente con el fin de establecer la relevancia del aporte, es importante diferenciar dos aspectos o niveles, que si bien pueden coincidir (parcialmente), deben ser valorados por separado. Por un lado, se tiene la contribución que hace la persona jurídica al grupo u organización que comete, por ejemplo, un crimen de lesa humanidad. Este sería el caso del suministro de bienes como el gas venenoso o incluso de dinero a una organización como la SS. Por otro lado, y como condición del aporte que realiza la empresa, se encuentra la contribución o acción concreta del acusado dentro de la persona jurídica y que facilita o hace posible la "acción cómplice" de esta última. Este sería el caso del gerente que ordena, autoriza o consiente que se entreguen al grupo que comete directamente el crimen los bienes mencionados. Si se toma como punto de referencia únicamente el crimen específico, fácilmente se puede centrar la atención solo en la "acción" de la persona jurídica, la cual puede no haber sido decisiva, si se quiere en el sentido de una conditio sine qua non, para la producción del resultado. Aunque, de todas maneras, no se debe perder de vista que esto no es necesario para que haya complicidad (la SS contaba, por ejemplo, con otros proveedores de Zyklon B y también con otras fuentes de financiación) ${ }^{103}$. Además, desde esta perspectiva, no habría mayor diferencia entre la decisión del gerente o de los miembros de la junta directiva de hacer negocios con el grupo u organización criminal y, por ejemplo, la asistencia técnica o apoyo administrativo que presta un empleado (subordinado) en cumplimiento de esa decisión, ya que las dos acciones contribuyen por igual desde el punto de vista causal, aunque de manera mediata, a la consumación del crimen. Es más, la acción del empleado podría estar materialmente más cerca al resultado delictivo final que la conducta del directivo, de lo cual no se desprende que esta sea normativamente más relevante que aquella. Por esta razón, además del crimen, también debe tenerse en cuenta el actuar de la persona jurídica, como punto de referencia para determinar la responsabilidad penal de sus miembros, ya que este constituye el contexto en que tienen lugar los comportamientos individuales.

Si es claro que la empresa realizó una contribución — suficientemente relevante desde el punto de vista jurídico-penal- que facilitó la comisión de crímenes por parte de un grupo u organización ilegal (primer nivel), la atención debe centrarse entonces en establecer la calidad de los aportes individuales que hicieron posible esa contribución (segundo nivel). Las acciones de los directivos, por un lado, y de los empleados subordinados, por otro, no tienen el mismo significado dentro de la empresa ni respecto a su funcionamiento. Así, quienes deciden sobre o autorizan una determinada política y en este sentido determinan el actuar de la persona jurídica, tienen un mayor grado de responsabilidad por lo que se hace en su nombre que aquellos que solo ejecutan esa política, pero no tienen poder de decisión. En este sentido, por ejemplo, la contribución del gerente es evidentemente más relevante que la del empleado, así la acción cómplice de la empresa haya 
sido, desde el punto de vista causal, producto de la suma de estas dos. En otras palabras: para fundamentar la responsabilidad penal a título de complicidad, la relevancia no debería predicarse solamente del aporte de la empresa al crimen como tal (lo cual en todo caso no debe perderse de vista) sino, además, de la contribución de la persona natural (es decir, del empresario) al accionar de esta última; después de todo, lo que constituye el objeto de análisis es la responsabilidad del individuo y no la de la persona jurídica.

La distinción entre la contribución que hace la persona jurídica (a la consumación del crimen) y la acción concreta del individuo (que tiene la facultad de decidir sobre los negocios que esta última realiza) da cuenta del carácter complejo de los crímenes internacionales, en la medida en que, como se ha afirmado recientemente ${ }^{104}$ , la relación entre el resultado y el comportamiento individual en estos contextos, por lo general, está mediada por un colectivo o grupo. En los casos que aquí interesan, por dos tipos de grupos que interactúan entre sí, uno que comete directamente el crimen y otro que realiza una contribución accesoria, cada uno con su propia estructura y niveles de responsabilidad. Además, de esta manera es posible centrar la persecución penal en aquellos que (normativamente) son más responsables ${ }^{105}$, a pesar de que material y causalmente hayan estado alejados de la consumación del crimen.

Con base en los procesos penales en contra de empresarios que tuvieron lugar después de la Segunda Guerra Mundial, también es posible afirmar, con relación a los casos (i) y (ii), es decir, cuando la empresa contribuye a la comisión de crímenes por parte de otra organización (criminal), que para fundamentar la responsabilidad de los directivos a título de complicidad no es necesario tener certeza sobre cuáles crímenes en concreto fueron cometidos como consecuencia del aporte realizado por la persona jurídica. Es decir, no se debería tener que probar con exactitud cuáles fueron los actos cometidos por la organización criminal sobre los que tuvieron efecto los aportes de la empresa ni las víctimas específicas producto de estos actos (no se tendría que probar en concreto qué día se utilizó el gas proporcionado por la empresa ni quiénes fueron asesinados con ese producto en ese preciso momento). Bastaría con establecer una conexión general entre el aporte y los actos criminales, siempre y cuando haya certeza sobre la existencia de aquel y la perpetración de estos. Es en este sentido que se ha hablado aquí de "crímenes indeterminados" al caracterizar los tipos de casos sobre empresarios que han sido relevantes en el ámbito internacional. Esto no aplicaría, sin embargo, cuando se trata de crímenes "cometidos" directamente por la empresa y por lo tanto sea posible hablar ya no de responsabilidad penal accesoria sino principal; en estos casos sí debe estar bien definido y delimitado el resultado de la conducta punible, así como la conexión específica entre estos dos elementos, y, dependiendo de los niveles de responsabilidad de los funcionarios involucrados y de sus aportes, se deben diferenciar las distintas formas de participación.

Desde el punto de vista subjetivo, una vez establecida la conducta concreta de cada individuo y su relevancia (normativa) frente a las actuaciones de la persona jurídica, se deber probar que se actuó de manera voluntaria y con conocimiento de la finalidad criminal del grupo al cual hizo su aporte la empresa. Así se exigió en todos los procesos aquí reseñados. Al respecto, es importante diferenciar entre el conocimiento o consciencia que puede tener un individuo solo sobre el carácter criminal, o tal vez mejor ilegal, de una determinada organización y el conocimiento sobre la intención de realizar conductas que pueden ser calificadas como crímenes internacionales y en este sentido sobre la posibilidad de que la contribución realizada estuviera destinada a facilitar su perpetración. Para fundamentar la responsabilidad penal del directivo empresario a título de complicidad en la comisión, por ejemplo, de crímenes de guerra o de lesa humanidad, no debe ser suficiente con probar solo lo primero, sino que se debe exigir incluso lo segundo ${ }^{106}$, ya que el fundamento último de la responsabilidad en estos casos no es el carácter ilegal como tal del grupo que recibe la ayuda sino los crímenes cometidos por este. De lo contrario, se abriría la puerta a imputaciones globales o generales por todos los crímenes que hayan podido cometer los miembros de una organización con la que desde la empresa se ha tenido contacto. Esto, por supuesto, dejaría en entredicho el principio de culpabilidad.

Si es posible determinar de alguna manera que el individuo (empresario) no solamente conocía la intención criminal de la organización sino que además la compartía, probablemente se entraría en el terreno de la coautoría, en donde además se requiere la existencia de un acuerdo común (para lo cual, claro está, se deben 
cumplir también los demás elementos de esta figura) ${ }^{107}$. En todo caso, se insiste, si se actúa voluntariamente dentro de la empresa, pues se conocen las intenciones criminales de la organización a la cual se presta algún tipo de servicio, se deberían tener por cumplidos los requisitos para la complicidad, así el empresario no comparta esa intención o su interés principal no sea la consumación de los crímenes ${ }^{108}$. Aunque, como lo afirmó el tribunal militar que decidió el caso Zyklon B, así se conozca la intención de la organización criminal, si la persona en cuestión no cumple con el aspecto objetivo (primer paso en el análisis de la responsabilidad), por ejemplo, en la medida en que no contaba con ningún poder de decisión sobre el accionar de la persona jurídica, no se podría fundamentar la responsabilidad penal accesoria. Esto sería un corolario no solamente del principio de culpabilidad sino también de entender el derecho penal como derecho penal de acto, en el cual el fundamento de la responsabilidad es la conducta concreta de la persona y no su personalidad o actitudes ${ }^{109}$.

\section{Responsabilidad penal de directivos empresariales por omisión}

En el ámbito internacional, también se ha discutido sobre la responsabilidad penal con base en la posición de superior jerárquico de algunos empresarios. Si bien no todos los casos del TPIR a los que se ha hecho referencia en este trabajo tienen qué ver con acciones ligadas directamente con los negocios o la actividad principal de la empresa ${ }^{110}$, estos son en todo caso relevantes en la medida en que permiten afirmar que los directivos de una persona jurídica pueden ser penalmente responsables por omisión, con fundamento en las acciones de quienes están subordinados a ellos ${ }^{111}$. En este contexto, se deben resaltar dos elementos fundamentales para esta forma de responsabilidad y que están directamente relacionados con el principio de culpabilidad: el control efectivo y el conocimiento sobre la conducta de los subordinados.

La existencia de control efectivo supone que el superior haya tenido la posibilidad real de evitar la consumación de los crímenes ${ }^{112}$ o, según la Cámara de Cuestiones Preliminares II de la Corte Penal Internacional, CPI, al menos que su omisión haya aumentado el riesgo de su perpetración ${ }^{113}$. Este elemento se debe evaluar atendiendo a las circunstancias de cada caso, entre las cuales, para determinar la responsabilidad penal de los empresarios, no solamente se encuentra la estructura (formal) de la empresa o compañía, sino también la manera real de funcionamiento y las relaciones de poder que en ella se forman (aunque el control efectivo en estos casos no debe ser exactamente del mismo tipo que habría en una relación de subordinación militar, al menos con relación a los poderes disciplinarios de los superiores militares) ${ }^{114}$. Por otro lado, para que haya responsabilidad con fundamento en la posición de superior, se debe tener conocimiento sobre la conducta de los subordinados y la omisión debe ser intencional. Aunque en el caso de Musema también se hizo alusión al desconocimiento negligente, siempre y cuando la negligencia hubiera sido de tal gravedad que fuera posible equipararla a la aquiescencia o consentimiento ${ }^{115}$, no se debe perder de vista que, por ejemplo, en el ER el elemento subjetivo para la responsabilidad penal de superiores no militares (como ocurriría en contextos empresariales) es más estricto que el previsto para jefes militares; en el primer caso (artículo 28 (b) (i) ER) se requiere que el superior haya "tenido conocimiento o deliberadamente hubiere hecho caso omiso de información que indicase claramente que los subordinados estaban cometiendo [los] crímenes o se proponían cometerlos" ${ }^{116}$, mientras que en el segundo caso (artículo 28 (a) (i) ER) es suficiente con que el superior, "en razón de las circunstancias del momento, hubiere debido saber" ${ }^{117}$. De todas maneras, la constatación de estos dos elementos (control efectivo y conocimiento) es indispensable para evitar caer en formas de responsabilidad objetiva ${ }^{118}$.

Por otro lado, se debe llamar la atención sobre lo dicho por la Cámara de Apelaciones con relación a Nabimana y Barayagwiza en cuanto a que no es necesario que los subordinados hayan cometido directamente el crimen, para que el superior que ha tenido control efectivo sobre estos pueda ser penalmente responsable. Esta afirmación permite resaltar la relación que existe entre la responsabilidad del superior (por omisión) 
y la complicidad (aunque — claro está- estas dos no se deben confundir). Por ejemplo, en el marco del ER, la omisión consciente de un superior (civil) que permite a sus subordinados cometer crímenes de lesa humanidad o de guerra, cuando dicha omisión ha tenido lugar "[c]on el propósito de facilitar la comisión" de estos crímenes, también puede dar lugar a responsabilidad penal con base en el artículo 25 (3) (c) ER (aiding and abetting) ${ }^{119}$, Es decir, las distintas formas de responsabilidad pueden ser concurrentes y la omisión de un superior puede constituir una contribución capaz de fundamentar la responsabilidad penal a título de complicidad ${ }^{120}$. En este caso, los autores principales pueden ser precisamente los subordinados que se benefician de la omisión del superior. Aunque, adicionalmente, en situaciones algo más complejas, por ejemplo, cuando es la empresa la que realiza una contribución como persona jurídica a la comisión de un crimen por parte de otra organización (ilegal), nada impediría que la omisión del superior, en este caso de los directivos de la empresa, pueda ser considerada como un aporte (accesorio) a la consumación (directa) del crimen por parte de miembros de esa otra organización o grupo. Aquí, los subordinados que pertenecen a la empresa pueden tener la condición de (co)autores (si actúan en conjunto con los miembros del grupo ilegal) o también pueden ser cómplices (si se dan los requisitos para esto, entre ellos, la relevancia del aporte según se indicó líneas arriba) o incluso, algunos de ellos pueden estar exentos de responsabilidad. Lo que interesa destacar es que el hecho de que el crimen haya sido cometido a través de la interacción de dos organizaciones distintas y que el aporte de los miembros de una de ellas haya consistido en una omisión, por ejemplo, para facilitar la contribución que la organización a la cual estos pertenecen hace a la otra, no excluye su responsabilidad penal.

\section{Responsabilidad penal de directivos empresariales y crímenes cometidos por grupos armados ilegales en Colombia}

Tomando como punto de referencia lo dicho con relación al DPI, a continuación, se plantearán algunas reflexiones, con énfasis en la JEP, sobre la responsabilidad penal de empresarios por violaciones de DDHH cometidas en Colombia por grupos armados. Así, se intentará definir cómo se pueden diferenciar los casos para cuyo juzgamiento son competentes los órganos que integran la JEP (suponiendo que el sometimiento a esta jurisdicción sea voluntario) de los casos para los que no y qué relación puede haber entre esta discusión y la pregunta por el grado de responsabilidad penal. Asimismo, se plantearán algunas consideraciones críticas sobre el argumento expuesto por la FGN en el sentido de aplicar en estos casos el tipo penal de concierto para delinquir, considerándolo como un crimen de lesa humanidad, para resaltar brevemente no solo los problemas dogmáticos que surgen de este argumento sino también la dificultad que implicaría acogerlo en la JEP.

\section{Definición de la competencia y formas de responsabilidad penal en la Jurisdicción Especial para la Paz}

Como se explicó en el apartado Contexto de la discusión en Colombia: de la Ley 975 de 2005 a la Jurisdicción Especial para la Paz, según el Acuerdo de Paz firmado entre el Gobierno y las FARC-EP, la JEP debía ser competente para juzgar la financiación de o colaboración con grupos armados, siempre que la persona (civil) en cuestión hubiera tenido una "participación activa o determinante" en la comisión de los crímenes que son de su competencia ${ }^{121}$. A pesar de que, como consecuencia del pronunciamiento de la Corte Constitucional, este requisito desapareció del Acto Legislativo 01 de 2017, la Ley de Amnistía (LA) sigue haciendo referencia, como criterio para establecer cuáles casos dan lugar a beneficios penales y cuáles en cambio se deben juzgar en la JEP, al menos, a la "participación determinante". Por esta razón, subsiste la necesidad de definir a qué se refiere esta expresión. 
En principio, se podría pensar que el requisito "participación determinante" hace alusión a la forma concreta de responsabilidad de cada individuo frente a la comisión de crímenes graves (incluso, crímenes equivalentes a crímenes internacionales), lo cual lleva a preguntarse si este se debe traducir en términos de la teoría general del delito, para diferenciar, por ejemplo, grados de participación o formas de responsabilidad y así definir cuáles casos de "financiación o colaboración" son de competencia de la JEP y cuáles no. Es decir, podría preguntarse, por ejemplo, si solo es posible afirmar que participaron de forma activa o determinante quienes hayan actuado como (co)autores o cuya conducta fue en estricto sentido activa, quedando por fuera de la JEP quienes tienen responsabilidad penal a título de complicidad u omisión. La definición que se había incluido en el artículo transitorio 16 y según la cual se entendía "por participación determinante para estos efectos aquella acción eficaz y decisiva en la realización de los delitos enunciados”, dificultaba aún más el panorama. Al respecto se debe advertir, sin embargo, que de aplicarse el criterio "participación determinante", el cual, se insiste, de todas maneras está previsto en el Acuerdo de Paz y en la Ley de Amnistía ${ }^{122}$, o cualquier otro, no resulta coherente ni conveniente, teniendo en cuenta los objetivos declarados de la JEP ${ }^{123}$, convertir la discusión sobre la competencia en un problema dogmático de grados de responsabilidad en términos de la teoría general del delito.

De aceptarse, por ejemplo, que con base en la expresión "participación determinante" la forma concreta de imputación o de responsabilidad constituye un factor relevante para definir la competencia de esta jurisdicción, se estarían confundiendo dos aspectos que deben estar separados: por un lado, la pregunta sobre la competencia material, la cual está delimitada por el conjunto de crímenes que, según el Acuerdo de Paz, habiendo sido cometidos en relación con el conflicto armado no son susceptibles de recibir beneficios penales como la amnistía o la renuncia a la persecución penal y, por otro lado, la forma concreta de responsabilidad que cada persona puede tener con base en esos crímenes. El primer aspecto constituye una pregunta preliminar que debe ser resuelta antes de que un juez realice cualquier valoración sobre la responsabilidad penal ${ }^{124}$, mientras que el segundo hace parte del juicio de imputación que realiza el juez al valorar jurídicamente los hechos probados $^{125}$. En otras palabras: lo primero da lugar a un problema "procesal”, mientras que lo segundo es una discusión eminentemente sustancial que, mientras no haya un reconocimiento anticipado de responsabilidad, debe resolverse en un juicio. Si se aceptara que la competencia de la JEP en cada caso concreto depende del grado de responsabilidad de cada civil, no sería suficiente con verificar que se está ante una conducta punible grave cometida por un grupo armado ilegal, sino que además se deberían constatar aspectos como la relación (objetiva y subjetiva) entre la conducta del empresario y la consumación del crimen o, por ejemplo, se tendría que definir si dicho empresario tuvo dominio del hecho y puede ser sancionado como coautor ${ }^{126}$. En consecuencia, se adelantaría la valoración del grado de responsabilidad para resolver una cuestión, como se ha dicho, preliminar, lo cual puede incluso generar debates probatorios complejos propios de etapas procesales distintas y posteriores, que se repetirían una y otra vez, lo cual afectaría la celeridad de los procesos.

Por lo anterior, con base en los criterios para la imputación de responsabilidad penal a directivos empresariales identificados en el apartado Criterios (mínimos) para la imputación de responsabilidad penal a directivos empresariales en casos de comisión de crímenes internacionales: entre la complicidad y la responsabilidad penal por omisión, aquí se propone diferenciar entre la contribución que hace la persona jurídica a la consumación del crimen y la acción concreta del individuo dentro de la persona jurídica, con el fin de separar la pregunta por el ámbito de competencia de la JEP del problema de la forma o grado de responsabilidad penal individual. De esta manera, es posible sostener que incluso los casos de responsabilidad penal a título de complicidad pueden ser conocidos por esta jurisdicción (siempre y cuando se cumplan los demás requisitos), sin importar la distancia que en términos físicos, causales o temporales pueda haber entre el aporte del sujeto y el resultado delictivo final. 


\section{Competencia de la Jurisdicción Especial para la Paz frente a empresarios y responsabilidad a título de complicidad}

En líneas generales, los criterios identificados arriba a partir de los casos relevantes en el DPI respecto a empresas que han contribuido o facilitado la comisión de crímenes por otras organizaciones y que permiten fundamentar la responsabilidad penal a título de complicidad son aplicables en Colombia. Dado que estos criterios, al menos en principio, constituyen una base mínima que permite definir y delimitar la responsabilidad penal individual (partiendo desde la complicidad), ofrecen elementos que pueden ser tenidos en cuenta por los órganos que integran la JEP, no solamente para definir su competencia frente a civiles sino también, en un paso posterior, para establecer la existencia y modalidad de responsabilidad penal. Así las cosas, con el fin de establecer la competencia de esta nueva jurisdicción (extraordinaria) con relación a casos en los cuales estén involucrados directivos empresariales, se debería examinar entonces, en primer lugar, la contribución que realizó la persona jurídica a la consumación del crimen. Si este aporte, visto objetivamente, cumple con las condiciones que en términos generales se han aceptado en el DPI para fundamentar (como primer paso) la responsabilidad a título de complicidad —es decir, es relevante frente a la forma de perpetración, sin que deba constituir una conditio sine qua non-, se debería aceptar que ese caso puede ser juzgado en la JEP.

De aceptarse entonces que el criterio "participación determinante" aún debe ser tenido en cuenta, lo "determinante" debería predicarse en realidad, para establecer la competencia, de la contribución de la persona jurídica a la perpetración del crimen. Podría decirse, como consecuencia, que es esta contribución la que debería haber sido "eficaz y decisiva" —en los términos que se habían previsto en el artículo transitorio 16 del AL 01 de 2017-, teniendo como punto de referencia la forma en que se cometió el crimen y no la producción del resultado ${ }^{127}$. Así, si hay elementos de juicio que indiquen que un grupo armado, del cual se sabe que cometió crímenes de competencia de esta jurisdicción, efectivamente recibió dinero de una empresa determinada, la JEP debería ser competente. Una vez aclarado esto, sí se podría pasar, posteriormente, a examinar la responsabilidad penal individual de los posibles responsables. En este segundo momento (que puede tener lugar en una etapa procesal distinta y ante un órgano diferente) sí se debería tener en cuenta la acción concreta del individuo dentro de la persona jurídica, ya que de esto depende en últimas la responsabilidad penal individual. Es más, también aquí tendrían que examinarse, respecto de cada individuo - y no de manera general frente a la persona jurídica como un todo- la existencia de posibles causales de ausencia de responsabilidad (como la coacción) ${ }^{128}$.

Lo "determinante" de la conducta concreta de cada individuo no sería entonces un factor para decidir sobre la competencia de la JEP y no se predicaría frente al crimen como tal. Sería más bien un elemento a valorar para definir si hay o no responsabilidad penal individual y en caso afirmativo en qué grado o modalidad. De hecho, el punto de referencia para establecer la relevancia del aporte de cada individuo debería ser el actuar "cómplice" de la persona jurídica, tal como se explicó líneas arriba, y no directamente el crimen cometido por el grupo armado ilegal. Por consiguiente, el hecho de que la contribución realizada por una empresa haya sido accesoria no impediría que, por ejemplo, el Tribunal para la Paz se pronunciara sobre la responsabilidad penal de sus directivos. Tampoco el hecho de que la conducta de estos haya estado alejada desde el punto de vista causal (incluso temporal y geográfico) de la perpetración del crimen debería ser un obstáculo para aceptar la competencia de la JEP. No se debe perder de vista que el Acuerdo de Paz mismo habla de participaciones indirectas en el conflicto, lo que abre la puerta para casos de contribuciones accesorias. Es decir, para que la JEP sea competente no se requeriría que ni el empresario ni la empresa como persona jurídica hayan cometido directamente la conducta punible, tampoco que la acción del empresario ni de la empresa hayan constituido una conditio sine qua non para la perpetración de crímenes concretos. 
Dejando de lado el problema de la competencia de la JEP, es posible concentrarse en la discusión sobre el grado de responsabilidad penal individual. En este contexto, como lo demuestran los casos reseñados en los apartados Tribunales penales militares instaurados con posterioridad a la Segunda Guerra Mundial y Tribunal Penal Internacional de Ruanda, ante crímenes cometidos por grupos u organizaciones distintas a la que pertenece el acusado y desde la cual se realizó algún tipo de aporte, surge como primera posibilidad de imputación la responsabilidad por complicidad. Al respecto es posible sostener, en líneas generales, que los criterios identificados en este trabajo con base en el DPI pueden orientar la interpretación del artículo 30 del Código Penal, CP, colombiano, que prevé la figura de los partícipes: el determinador y el cómplice. En todo caso, al respecto se deben hacer algunas precisiones.

Se debe señalar, en primer lugar, que en Colombia se ha discutido sobre la relevancia del aporte, aunque con la finalidad de diferenciar, sobre todo, la autoría de la complicidad y no tanto para establecer cuándo la realización de un aporte accesorio es o no punible ${ }^{129}$. En este sentido, incluso se ha llegado a afirmar que las contribuciones esenciales para la producción del resultado criminal (lo que según la distinción clásica podría considerarse como "complicidad necesaria") dan lugar en realidad a la coautoría, mientras que solo las contribuciones menos relevantes, no esenciales para la producción del resultado (es decir, la "complicidad no necesaria"), fundamentarían la complicidad ${ }^{130}$. Como consecuencia, todos los aportes que se hacen desde una empresa y que facilitan la comisión de crímenes por parte de grupos armados serían susceptibles de ser sancionados penalmente conforme al artículo $30 \mathrm{CP}$, sin importar la condición de las personas que los realizan, es decir, si lo hicieron como directivos o como empleados sin verdadero poder de decisión. De esta manera, el ámbito de la complicidad sería más amplio en el derecho penal colombiano que de acuerdo con los casos internacionales a los que se ha hecho referencia ${ }^{131}$. Sin embargo, en Colombia puede tenerse en cuenta la teoría del aumento del riesgo, como elemento de la teoría de la imputación objetiva. Así lo ha aceptado recientemente la Corte Suprema de Justicia (CSJ) a pesar de que, al parecer, no hay una línea jurisprudencial decantada al respecto ${ }^{132}$. Es decir, aportes poco significativos desde el punto de vista normativo podrían excluirse de la complicidad, dado que no aumentan el riesgo de producción del resultado lesivo, a pesar de que el Código Penal colombiano, al definir esta forma de responsabilidad, no exige expresamente un determinado estándar, como por ejemplo, en los términos de los tribunales ad hoc, realizar un aporte sustancial ${ }^{133}$.

Así las cosas, en Colombia también se podría tener en cuenta, para fundamentar la responsabilidad penal, la diferencia arriba propuesta entre la contribución que hace la persona jurídica (a la consumación del crimen) y la acción concreta del individuo (que tiene la facultad de decidir sobre los negocios que esta última realiza). Una vez probado lo primero (de lo cual, de acuerdo con la propuesta que se hace en este texto, podría depender la competencia de la JEP), es posible ubicar la discusión en el ámbito de la complicidad como forma mínima de responsabilidad en casos de crímenes graves cometidos por miembros de otro grupo u organización (ilegal); en este contexto, lo segundo sería relevante como factor para evaluar la imputación desde el punto de vista objetivo.

Por otro lado, se debe señalar que en Colombia el artículo 30 CP exige como elemento de la complicidad un "concierto previo o concomitante". Este elemento no se encuentra en la forma como se ha entendido la complicidad en el DPI. La pregunta entonces es si en el contexto colombiano basta con tener conocimiento sobre la intención que tiene otra persona u organización de cometer crímenes o si también se debe exigir un acuerdo dirigido específicamente a su facilitación. Es decir, en principio puede ser diferente llegar a un acuerdo concretamente dirigido a prestar/recibir una contribución para facilitar la comisión de ciertos crímenes (por ejemplo: la empresa $X$ acepta la propuesta hecha por el grupo armado $Y$ y acuerda pagarle una suma de dinero con el fin de diezmar y debilitar al sindicato de trabajadores, lo que conduce a la desaparición forzada, tortura y homicidio de empleados de la empresa a manos de los miembros de dicho grupo) a llegar a un acuerdo en virtud del cual se realiza una contribución, pero que no supone (como "contraprestación") la realización de hechos punibles, aunque se sabe que esto sucederá (por ejemplo: la empresa $X$ acuerda con el 
grupo armado $Y$, conociendo las intenciones criminales de este último, que le pagará una determinada suma de dinero a cambio de vigilar el transporte de mercancías y evitar que sus camiones sean atacados por otro grupo armado; con ese dinero, el grupo $\mathrm{Y}$ adquiere armas y medios de transporte que son utilizados en operaciones de "limpieza social" en la región donde funciona la empresa, lo cual genera desplazamiento forzado de la población civil). En el primer caso, el objeto del "concierto" no es solo entregar el dinero, sino también atacar el sindicato, mientras que en el segundo caso el desplazamiento forzado no es parte del acuerdo, aunque con su cumplimiento y a sabiendas se haya facilitado la consumación de ese crimen. Al respecto, se debe anotar que el artículo $30 \mathrm{CP}$ no exige expresamente que el acuerdo o "concierto previo o concomitante" esté específicamente dirigido a la comisión del crimen. Por esta razón, desde una interpretación literal del artículo 30, la pregunta sobre el conocimiento e intención del cómplice se mantiene abierta. En consecuencia, sería posible aceptar la complicidad ante la existencia de un acuerdo, en el marco del cual ha tenido lugar la contribución accesoria, cuando quien realiza esa contribución (en este caso, el o los directivos de la empresa) sabía que así estaba facilitando la comisión de ciertos hechos punibles, aun cuando el acuerdo no haya estado dirigido específicamente a esto. De ahí que, en el contexto colombiano los dos ejemplos mencionados cumplirían con este requisito, así como también ocurriría conforme a las decisiones internacionales que aquí se han reseñado, no obstante las discusiones que al respecto existen, por ejemplo, respecto a la jurisprudencia de los tribunales ad hoc y el ER ${ }^{134}$.

Es importante aclarar que el hecho de que el cómplice tenga que actuar con dolo ${ }^{135}$ no impide llegar a la anterior conclusión. En este sentido, es claro que la complicidad exige conocimiento sobre la intención del autor de cometer el o los crímenes respectivos; la pregunta es entonces qué tanto conocimiento se requiere y cómo influye esto sobre el elemento volitivo de esta figura. Al respecto, la CSJ parece inclinarse por una visión más bien restrictiva, al exigir un plan que sea en sí mismo criminal, acorde con el cual el cómplice actúa con la voluntad específica de contribuir a un crimen concreto ${ }^{136}$; es decir, de acuerdo con esta postura, no sería suficiente con saber que se está facilitando la comisión de un crimen, si no hay un acuerdo entre autor y cómplice, por el cual este último haya aceptado ser parte (participar) de la comisión de una conducta punible plenamente identificable ${ }^{137}$. De esta manera, en el segundo ejemplo arriba mencionado no se cumpliría con el elemento subjetivo de la complicidad. Sin embargo, este criterio ha sido utilizado por la CSJ en casos de criminalidad "ordinaria", lo que permite preguntarse si resulta adecuado para eventos de violencia masiva y conductas equivalentes a crímenes internacionales y si resultaría admisible modificarlo ante este tipo de situaciones. En este sentido, la doctrina (incluso nacional) facilita un poco el asunto, pues en ella se ha reconocido que el cómplice actúa con "doble dolo", lo que permite hacer ciertas diferenciaciones sobre el objeto del mismo ${ }^{138}$. Esto quiere decir que el dolo del cómplice tiene dos puntos de referencia: por un lado, el dolo se dirige a la conducta accesoria que él mismo realiza y, por otro lado, a la lesión, por parte del autor, del bien jurídico protegido ${ }^{139}$. Así, respecto del segundo punto de referencia, sería suficiente con saber qué planea hacer el autor, sin que sea necesario conocer la dimensión aproximada del daño en concreto o los detalles del ataque planeado o participar en esa planeación; bastaría entonces con prever que el autor va a cometer una determinada conducta punible ${ }^{140}$. Si se sigue este enfoque, es posible sostener que los directivos de una empresa actúan dolosamente en el sentido exigido por la complicidad, si saben que un grupo armado atentará contra la población civil y que el dinero o las armas que ellos, a través de la empresa, le entregan al grupo lo facilitarán.

\section{Competencia de la Jurisdicción Especial para la Paz frente a empresarios y responsabilidad por omisión}

La expresión "participación activa o determinante" y la definición adoptada inicialmente en el artículo transitorio 16 del Acto Legislativo 01 de 2017 de "participación determinante" también permiten 
preguntarse si los casos de "participación" por omisión quedarían excluidos. La interpretación literal de lo dispuesto tanto en el Acuerdo de Paz, como en el artículo transitorio 16 parecía conducir a esta conclusión. Desde esta perspectiva, habría al menos dos posibilidades y ambas podrían llevar al mismo resultado. Las expresiones "activa" y "determinante" podrían ser consideradas como sinónimos o podrían ser interpretadas como dos condiciones distintas que podrían cumplirse de forma disyuntiva. En el primer evento, la omisión estaría excluida desde el Acuerdo de Paz mismo, en el cual se incorporó el criterio "participación activa o determinante" (cursivas por fuera del texto original) para definir la competencia de la JEP. Mientras que, si se opta por la segunda alternativa, la admisión o no de la omisión dependería de qué se entienda por participación "determinante". Claro, de acogerse una definición como la que se había incluido en el artículo transitorio 16 ("aquella acción eficaz y decisiva"), la omisión también estaría excluida en este supuesto.

Esta interpretación del criterio "participación activa o determinante" puede reducir en exceso el ámbito de competencia de la JEP ante crímenes graves, cuya perpetración debe ser sancionada. Como los casos reseñados en el apartado Tribunal Penal Internacional de Ruanda de este trabajo permiten ver, precisamente la omisión constituye una forma de intervención en la comisión de crímenes internacionales, la cual adquiere especial relevancia desde el punto de vista normativo en estructuras complejas y jerárquicas. En este tipo de organizaciones, no actuar en uno u otro sentido por parte de quienes ostentan posiciones de poder puede ser decisivo, no solamente frente a la conducta de los subordinados, sino también con relación a las acciones de la organización misma; máxime cuando la inacción puede ser interpretada como aprobación de determinadas políticas o líneas de conducta.

Para evitar esta situación, en este contexto también podría tenerse en cuenta la distinción aquí planteada entre la contribución que hace la persona jurídica a la consumación del crimen y la contribución concreta del individuo dentro de la persona jurídica, con el fin de separar la pregunta por el ámbito de competencia de la JEP del problema de la forma o grado de responsabilidad penal individual. Como se indicó líneas arriba, la "participación determinante" se predicaría, para efectos de establecer la competencia de la JEP, de la contribución de la persona jurídica a la perpetración del crimen, mientras que, en un segundo paso -habiéndose resuelto el problema de la competencia-, sí sería posible valorar la conducta concreta de cada individuo dentro de la persona jurídica, con el fin de establecer su responsabilidad. Esta conducta podría entonces haber consistido en una omisión. La pregunta subsiguiente sería entonces qué tipo de responsabilidad sería posible fundamentar sobre esta base. En este sentido, podría acudirse a la figura de la comisión por omisión, para lo cual sería en todo caso necesario fundamentar la existencia de posición de garante en cabeza de los líderes empresariales - este tema presenta dificultades adicionales y requeriría un análisis más detallado— ${ }^{141}$, o podría acudirse nuevamente a la complicidad como forma básica de imputación para este tipo de casos, dado que en el ámbito nacional también se ha aceptado la complicidad omisiva ${ }^{142}$. De esta manera, por ejemplo, los directivos de una empresa que tienen conocimiento sobre los acuerdos a los que han llegado con un grupo armado ilegal, por decir algo, los empleados encargados de la seguridad de la compañía, y que no toman ninguna medida para evitar que esto siga sucediendo podrían ser considerados cómplices si la empresa, producto de dichos acuerdos, realiza un aporte relevante que facilita la comisión de crímenes como homicidios y torturas (bajo el supuesto de que dichos directivos también conocieran la intención criminal del grupo armado, tal y como se explicó en el apartado anterior).

\section{Financiación de grupo armados ilegales: ¿concierto para delinquir agravado como crimen de lesa humanidad?}

Ante casos de financiación de grupos armados también existe la posibilidad de acudir al tipo penal de concierto para delinquir previsto en el artículo 340 del Código Penal ${ }^{143}$, cuya pena se agrava cuando el concierto se realiza para cometer los crímenes enunciados en el segundo inciso de esta misma norma ${ }^{144}$. La 
FGN no solamente ha sostenido que la financiación de grupos armados por parte de empresarios puede ser enmarcada en este tipo penal, sino también que esta conducta en sí misma puede considerarse como un crimen de lesa humanidad ${ }^{145}$. Para esto, la FGN se ha basado en la jurisprudencia de la Corte Suprema de Justicia, por ejemplo, en casos relacionados con la Ley de Justicia y Paz, LJP ${ }^{146}$, lo cual ha servido de "estrategia" para justificar ciertas consecuencias, como por ejemplo, la imprescriptibilidad de la acción penal ${ }^{147}$. Aunque estas afirmaciones y los argumentos expuestos por la FGN para soportarlas exigen un análisis detallado y aparte, aquí deben bastar las siguientes consideraciones, con el fin de ilustrar brevemente los siguientes puntos: (i) los problemas que surgen a la luz del principio de culpabilidad al considerar el concierto para delinquir como crimen de lesa humanidad; (ii) la debilidad de la alusión al DPI como fundamento del argumento de la FGN; y (iii) la contradicción que implicaría aceptar esta "hipótesis" en el marco de la JEP, teniendo en cuenta lo estipulado en el Acuerdo firmado con las FARC.

Con relación al primero de estos tres aspectos se debe señalar, que la aplicación del concierto para delinquir, considerado como crimen de lesa humanidad, lleva a que el individuo a quien se imputa este tipo penal sea sancionado con fundamento en la pertenencia o contacto que ha tenido con un determinado grupo y deba, además, soportar ciertas consecuencias jurídico penales que se derivan de las acciones delictivas de ese grupo, sin que él necesariamente haya participado en su comisión, o por lo menos sin que esto se haya probado. De esta forma, la FGN se "libera" de las cargas argumentativas y probatorias que supone soportar una acusación por delitos tan complejos como los crímenes de lesa humanidad. Así, por ejemplo, la discusión sobre los criterios de imputación de crímenes más concretos, que han sido cometidos por grupos armados, a terceros que han apoyado a estos grupos pasa a un segundo plano. Dicho de otra manera: mediante esta "estrategia" la FGN evita tener que establecer la relación fáctica y normativa entre el aporte individual de la persona (empresario), cuya responsabilidad penal se analiza en el caso concreto, y el resultado criminal producto de las acciones del grupo armado. Como consecuencia, por ejemplo, si se sigue esta lógica, la pregunta sobre la relevancia del aporte del posible cómplice no debe ser resuelta. Sin embargo, no se debe olvidar que el concierto para delinquir se configura únicamente mediante un acuerdo o la pertenencia a un grupo y en este sentido es un tipo penal no solamente de ejecución permanente sino también de mera conducta ${ }^{148}$, mientras que para hablar de crímenes de lesa humanidad además del ataque (generalizado o sistemático) contra la población civil, es necesario que se den uno o varios de los hechos individuales incluidos, por ejemplo, en el artículo 7 (1) ER. Estos hechos individuales suponen resultados delictivos no solamente graves sino además tangibles: homicidios, torturas, violaciones, etc., y constituyen aquello que se imputa, así como el fundamento del reproche cuando se condena por un crimen de lesa humanidad. Por esta razón, si de acuerdo con el principio de culpabilidad la pena se debe fundar en aquello que cada persona ha hecho (responsabilidad penal individual, no grupal), cabe preguntarse si la sola circunstancia de haber realizado un acuerdo — por ejemplo, para entregar armas o dinero a un grupo- puede sin más hacer responsable a una persona por las acciones que ese grupo ha realizado. Esto se hace aún más problemático si se trata de establecer dentro de una persona jurídica, teniendo en cuenta su estructura y funcionamiento, quiénes tienen y quiénes no tienen responsabilidad penal por los negocios realizados por ella. La alusión al concierto para delinquir tiende entonces a facilitar juicios de responsabilidad generales y esconde el problema real de estos casos, es decir, la identificación de aportes concretos a la comisión de crímenes graves por medio de estructuras complejas.

Adicionalmente, es importante no perder de vista, tal como lo ha afirmado la FGN, que mediante el concierto para delinquir la legislación penal colombiana criminaliza "un acto preparatorio" ${ }^{149}$. Sin embargo, en el DPI no existe una figura mediante la cual se haga lo mismo, de manera que la referencia a esta rama del derecho con el fin de justificar este argumento también resulta bastante problemática. En primer lugar, como ya se mencionó, los crímenes de lesa humanidad suponen daños concretos y entre las conductas que han sido catalogadas como tal no se ha incluido ningún tipo de crimen de asociación, conspiración o similar ${ }^{150}$. Tanto es así que en la enumeración de conductas que hace el ER, la cláusula abierta de "otros actos inhumanos" ha 
sido delimitada mediante elementos que hacen énfasis en la producción de un daño comparable a las demás conductas incluidas en el artículo 7 (1) de ese Estatuto ${ }^{151}$. Pero, además, el desarrollo del DPI evidencia un esfuerzo por establecer criterios de imputación que, precisamente, permitan respetar el principio de responsabilidad penal individual. Es decir, la tendencia ha estado dirigida a definir formas de participación en este tipo de crímenes, que den cuenta de su carácter colectivo, pero sin dar lugar a formas de responsabilidad objetiva. Figuras como la empresa criminal conjunta, ECC, en sus tres formas ${ }^{152}$ - a pesar de las críticas de las que ha sido objeto (sobre todo, la ECC III) — ${ }^{153}$, y la adopción de la teoría del dominio de la organización por parte de la CPI ${ }^{154}$ obedecen justamente a este propósito. Mediante la combinación de diferentes elementos, tanto objetivos como subjetivos, estas figuras hacen posible la atribución de responsabilidad a quien ha tomado parte en la perpetración de las conductas que sí constituyen crímenes de lesa humanidad. De hecho, en el DPI, la pertenencia como tal a un grupo solamente fue considerada como un crimen al finalizar la Segunda Guerra Mundial, sin que esto haya sido previsto nuevamente en los estatutos de los tribunales penales internacionales contemporáneos ${ }^{155}$; más aún, incluso en el contexto de la posguerra, el TPM de Núremberg hizo un esfuerzo por respetar el principio de culpabilidad y limitó la aplicación de esta figura ${ }^{156}$.

En el marco de la JEP, la calificación de la financiación de grupos armados como crimen de lesa humanidad generaría, además, problemas adicionales, ya que se entraría en contradicción con lo previsto en el Acuerdo de Paz. De hecho, esto podría desarticular el sistema de justicia transicional allí previsto, ya que de esta forma conductas que deberían ser objeto de beneficios penales se transformarían en conductas que deberían ser juzgadas. Al respecto, se debe recordar que la lista de crímenes frente a los cuales no proceden la amnistía y el beneficio de renuncia a la persecución penal, no incluye el concierto para delinquir, como sí sucede con los crímenes de lesa humanidad ${ }^{157}$. Más aún, de acuerdo con el artículo 23 de la Ley 1820 de 2016, son consideradas como delitos conexos con el delito político las "conductas dirigidas a facilitar, apoyar, financiar u ocultar el desarrollo de la rebelión" (cursivas por fuera del texto original), de tal forma que, quienes hayan financiado a las FARC y solo tengan responsabilidad por esa conducta no deberían ser juzgados por el Tribunal para la Paz.

Algo similar ocurre con la financiación de grupos paramilitares, pues, como ya se explicó, también en estos eventos el mismo Acuerdo hace un esfuerzo para diferenciar entre casos en los que habiendo algún tipo de responsabilidad proceden beneficios penales y por lo tanto no deberían ser juzgados por la JEP y los que sí deben serlo. Así pues, la pregunta sobre el vínculo entre el tercero (empresario) y los crímenes concretos cometidos por el grupo armado ilegal no puede ser ignorada mediante la aplicación de un tipo penal que solo castiga la conformación de una asociación criminal. No se debe olvidar que desde el Acuerdo de Paz se previó que la Sala de Definición de Situaciones Jurídicas puede conceder la renuncia a la persecución penal a civiles no combatientes y que aquellas personas respecto de las cuales hay "procesos o condenas por delitos que son competencia de la JEP”, pueden presentarse voluntariamente ante esta Sala para que les sea definida su situación jurídica, "cuando no hayan tenido una participación determinante en los delitos más graves y representativos" ${ }^{158}$, entre ellos, los crímenes de lesa humanidad.

\section{Consideraciones finales}

Como conclusión es posible afirmar que, a pesar del fallo de la Corte Constitucional, mediante el cual la competencia de la JEP frente a civiles quedó supeditada a su sometimiento voluntario, la discusión sobre la distinción entre casos que posibilitan recibir algún tipo de beneficio como la amnistía o la renuncia a la persecución penal y los casos que en este contexto generan responsabilidad penal sigue siendo relevante. En este sentido, se requiere algún criterio que permita realizar esta distinción. La idea de "participación determinante", prevista inicialmente en el Acuerdo y en la Ley de Amnistía con esta finalidad, podría ser 
tenida en cuenta a pesar de la declaratoria de inconstitucionalidad del inciso segundo del artículo transitorio 16 del Acto Legislativo 01 de 2017, en donde no solamente estaba contemplada sino también se definía. Este criterio, en todo caso, no debe ser interpretado como una restricción de la competencia de la JEP para juzgar civiles, en el sentido de excluir formas de participación en o de comisión de los crímenes. Como se explicó a lo largo de este trabajo, la definición de la competencia y la definición del grado de responsabilidad penal constituyen dos problemas distintos que se deben separar. De esta manera, la JEP sería competente incluso para casos de complicidad, teniendo en cuenta que esta representa la forma básica de imputación reconocida, por ejemplo, en el DPI, para tratar la responsabilidad penal de civiles por crímenes cometidos por grupos armados o regímenes criminales.

Esta discusión también permite afirmar, de manera más general, que la persecución penal de conductas que constituyen crímenes internacionales impone retos especiales a la administración nacional de justicia, los cuales son difíciles de asumir, no solamente por la complejidad propia de este tipo de criminalidad, sino también debido a la indignación que causan formas degradadas de violencia. Sin embargo, esta situación no exonera a los operadores judiciales de llevar a cabo una argumentación consistente para soportar sus decisiones. En cumplimiento de esta tarea, resulta fundamental buscar alternativas que permitan dar respuestas idóneas desde el punto de vista político-criminal, lo que supone construir a partir del derecho vigente argumentos plausibles y adecuados a los fenómenos objetos de valoración, sin perder de vista la necesidad de respetar principios básicos de los que depende la legitimidad del ejercicio del poder punitivo del Estado, como el principio de culpabilidad, aun en contextos de justicia transicional. La participación de civiles, como sucede con los directivos empresariales, en los crímenes cometidos por los grupos armados constituye, en este sentido, tal vez una de las situaciones más complejas de valorar jurídico-penalmente. Para esto, tal como se ha mostrado en este trabajo, es posible acudir al DPI, con el fin de identificar criterios para tratar este tipo de casos. Estos criterios, sin embargo, no se pueden trasladar automáticamente al ámbito nacional sin un análisis cuidadoso de su compatibilidad. Adicionalmente, la referencia al DPI debe llevarse a cabo con cierta precisión, reconociendo sus matices, para evitar lecturas equivocadas tanto de su desarrollo como de su estado actual. Así las cosas, órganos como los que componen la JEP y que se deben ocupar de estos temas, tienen el deber de desentrañar el complejo sistema de fuentes del derecho que deberá ser aplicado en esta nueva jurisdicción, con el fin de articular el ordenamiento jurídico interno con el internacional y así proferir decisiones suficientemente sólidas, lo cual resulta decisivo para su legitimidad.

\section{Bibliografía}

\section{Libros}

AMBOS, KAI, The ICC and Common Purpose - What Contribution is Required under Article 25(3)(d)?, en The Law and Practice of the International Criminal Court, 592-607 (CARSTEN STAHN, ed., Oxford University Press, Oxford, 2015).

AMBOS, KAI, Treatise on International Criminal Law, Volume I: Foundations and General Part (Oxford University Press, Oxford, 2013).

AMBOS, KAI, Treatise on International Criminal Law, Volume II: The Crimes and Sentencing (Oxford University Press, Oxford, 2014).

BURGHARDT, BORIS, Die Vorgesetztenverantwortlichkeit im völkerrechtlichen Straftatsystem (Berliner Wissenschafts-Verlag, Berlin, 2008).

CASSESE, ANTONIO \& GAETA, PAOLA, Cassese's International Criminal Law (Oxford University Press, Oxford, 2013).

CENTRO NACIONAL DE MEMORIA HISTÓRICA, CNMH, Justicia y Paz. Tierras y territorios en las versiones de los paramilitares (CENTRO NACIONAL DE MEMORIA HISTÓRICA, CNMH, Bogotá, 2014). Disponible en: http://www.centrodememoriahistorica.gov.co/justicia-y-paz/tierras-y-territorios-en-las-version es-de-los-paramilitares 
CENTRO NACIONAL DE MEMORIA HISTÓRICA, CNMH, La maldita tierra. Guerrilla, paramilitares, mineras y conflicto armado en el departamento de Cesar (CENTRO NACIONAL DE MEMORIA HISTÓRICA, CNMH, Bogotá, 2016). Disponible en: http://www.centrodememoriahistorica.gov.co/descarg as/informes2016/maldita-tierra/la-maldita-tierra.pdf

Corpus Juris Secundum, Volume 19 (American Law Book Co., Brooklyn, New York, 1940).

CRYER, ROBERT; FRIMAN, HÅKAN; ROBINSON, DARRYL \& WILMSHURST, ELIZABETH, An Introduction to International Criminal Law and Procedure (Cambridge University Press, Cambridge, 2014).

FERNÁNDEZ-CARRASQUILLA, JUAN, Derecho penal, Parte general, Vol. 2, Dispositivos amplificadores, concursos y pena (Editorial Ibáñez, Bogotá, 2012).

JACKSON, MILES, Complicity in International Law (Oxford University Press, Oxford, 2015).

JÄGER, HERBERT, Makrokriminalität \# Studien zur Kriminologie kollektiver Gewalt (Suhrkamp, Frankfurt am Main, 1989).

KAUFMANN, ARTHUR, Das Schuldprinzip. Eine strafrechtlich-rechtsphilosophische Untersuchung (Carl Winter Universitätsverlag, Heidelberg, 1976).

MAURACH, REINHART; GÖSSEL, KARL \& ZIPF, HEINZ, Strafrecht Allgemeiner Teil, Teilband 2: Erscheinungsformen des Verbrechens und Rechtsfolgen der Tat (C. F. Müller, Heidelberg, 2014).

MURMANN, UWE, Grundkurs Strafrecht: Allgemeiner Teil, Tötungsdelikte, Körperverletzungsdelikte (C. H. Beck, München, 2015).

PARK, KYUNG-GYU, Rechtsnatur, konkrete Voraussetzungen und Legitimität der Beteiligungsform gemäß Art. 25 Abs. 3 lit. (d) IStGH-Statut (Duncker \& Humblot, Berlin, 2016).

ROXIN, CLAUS, Strafrecht Allgemeiner Teil, Band I: Grundlagen. Der Aufbau der Verbrechenslebre (C. H. Beck, München, 2006).

ROXIN, CLAUS, Strafrecht Allgemeiner Teil, Band II: Besondere Erscheinungsformen der Straftat (C. H. Beck, München, 2003).

SCHABAS, WILLIAM, The International Criminal Court. A Commentary of the Rome Statute (Oxford University Press, Oxford, 2016).

SUÁREZ-SÁNCHEZ, ALBERTO, Autoria (Universidad Externado de Colombia, Bogotá, 2007).

VELÁSQUEZ-VELÁSQUEZ, FERNANDO, Manual de derecho penal. Parte general (Ediciones Jurídicas Andrés Morales, Bogotá, 2014).

VEST, HANS, Völkerrechtsverbrecherverfolgen. Ein abgestuftes Mehrebenenmodell systemischer Tatherrschaft (Stämpfli Verlag AG, Bern, 2011).

WERLE, GERHARD \& JESSBERGER, FLORIAN, Völkerstrafrecht (Mohr Siebeck, Tübingen, 2016).

\section{Colaboración en obras colectivas}

HERNÁNDEZ-ESQUIVEL, ALBERTO, Autoría y participación, en Lecciones de derecho penal, Parte general, 267-306 (Universidad Externado de Colombia, Bogotá, 2011).

LONDOÑO-MESA, FEDERICO, Concurso de personas en la conducta punible, en Derecho penal. Parte general Fundamentos, 547-590 (LEONARDO DAVID LÓPEZ-ESCOBAR, ed., Universidad de Medellín, Medellín, 2011).

MARXEN, KLAUS, Beteiligung an schwerem systematischen Unrecht - Bemerkungen zu einer völkerstrafrechtlichen Straftatlehre, en Aufgeklärte Kriminalpolitik oder Kampf gegen das Böse?, Band III, Makrokriminalität, 220-236 (KLAUS LÜDERSSEN, ed., Nomos, Baden-Baden, 1998).

OHLIN, JENS DAVID, Co-Perpetration, German Dogmatik or German Invasion?, en The Law and Practice of the International Criminal Court, 517-537 (CARSTEN STAHN, ed., Oxford University Press, Oxford, 2015). 
SÁNCHEZ, NELSON CAMILO, Corporate Accountability, Reparations, and Distributive Justice in PostConflict Societies, en Corporate Accountability in the Context of Transitional Justice, 114-131 (SABINE MICHALOWSKI, ed., Routledge, London, New York, 2013).

TRIFFTERER, OTTO \& ARNOLD, ROBERTA, Article 28, Responsibility of Commanders and Other Superiors, en The Rome Statute of the International Criminal Court. A Commentary, 1101-1103 (OTTO TRIFFTERER \& KAI AMBOS, eds., C. H. Beck, Hart, Nomos, München, 2016).

\section{Revistas}

BOCK, STEFANIE, Zurechnung im Völkerstrafrecht, 7-8 Zeitschrift für Internationale Strafrechtsdogmatik, ZIS, 410-427 (2017). Disponible en: http://zis-online.com/dat/artikel/2017_7-8_1125.pdf

COTE-BARCO, GUSTAVO, Responsabilidad del superior jerárquico y responsabilidad penal por omisión de miembros de la Fuerza Pública en Colombia: ¿convergencia entre el derecho penal nacional e internacional?, 28 International Law, Revista Colombiana de Derecho Internacional, 49-112 (2016). Disponible en: https://revistas.javeriana.ed u.co/index.php/internationallaw/article/view/18207

FARRELL, NORMAN, Attributing Criminal Liability to Corporate Actors. Some Lessons from the International Tribunals, 8 Journal of International Criminal Justice, 3, 873-894 (2010). https://doi.org/10.1093/jicj/mqq030

FLETCHER, GEORGE P. \& OHLIN, JENS DAVID, Reclaiming Fundamental Principles of Criminal Law in the Darfur Case, 3 Journal of International Criminal Justice, $539-561$ (2005). Disponible en: https://scholarship.la w.cornell.edu $/ \mathrm{cgi} /$ viewcontent.cgi?article $=1497 \&$ context $=$ facpub

GARCÍA, ALEXANDRA, Corporate Liability for International Crimes: A Matter of Legal Policy since Nuremberg, 24 Tulane Journal of International and Comparative Law, 97-129 (2015-2016).

KARSTEN, NORA, Distinguishing Military and Non-Military Superiors: Reflections on the Bemba Case at the ICC, 7 Journal of International Criminal Justice, 5, 983-1004 (2009). DOI: 10.1093/jicj/mqp071

MELONI, CHANTAL, Command Responsibility. Mode of Liability for the Crimes of Subordinates or Separate Offence of the Superior?, 5 Journal of International Criminal Justice, 3, 619-637 (2007). https://doi.org/10.1093/jicj/m qm029

MURMANN, UWE, Problems of Causation with Regard to (Potential) Actions of Multiple Protagonists, 12 Journal of International Criminal Justice, 2, 283-294 (2014). https://doi.org/10.1093/jicj/mqu018

NERLICH, VOLKER, Core Crimes and Transnational Business Corporations, 8 Journal of International Criminal Justice, 3, 895-908 (2010). https://doi.org/10.1093/jicj/mqq039

VEST, HANS, Business Leaders and the Modes of Individual Criminal Responsibility under International Law, 8 Journal of International Criminal Justice, 3, 851-872 (2010). https://doi.org/10.1093/jicj/mqq032

WILT, HARMEN VAN DER, Corporate Criminal Responsibility for International Crimes: Exploring the Possibilities, 12 Chinese Journal of International Law, 1, 43-77 (2013). https://doi.org/10.1093/chinesejil/jmt010

\section{Normativa internacional}

Allied Control Council, Control Council Law No. 10, Punishment of Persons Guilty of War Crimes, Crimes against Peace and against Humanity [Kontrollratsgesetz Nr. 10], 20 December 1945. Disponible en: http://avalon.law .yale.edu/imt/imt10.asp

Charter of the International Military Tribunal, IMT [Estatuto del Tribunal Penal Militar de Núremberg, TPM], 8 August 1945. Disponible en: http://avalon.law.yale.edu/imt/imtconst.as p, http://www.cruzroja.es/principal/documents/1750782/1852538/estatuto_del_tribunal_de_nuremberg.pd f/20090fa2-e5bf-447a-aa96-612403df2a66

International Committee of the Red Cross, ICRC, Rules of International Humanitarian Law and Other Rules Relating to the Conduct of Hostilities (International Committee of the Red Cross, Geneva, 1989). Disponible 
en: https://shop.icrc.org/droit-international-regissant-la-conduite-des-hostilites-collection-des-conventions-d e-la-haye-et-de-certains-autres-traites-2646.html

Naciones Unidas, Consejo de Seguridad, Resolución 955, Establecimiento de un Tribunal Internacional y aprobación del Estatuto del Tribunal Penal Internacional, 8 de noviembre de 1994. Disponible en: https://undocs.org/es/ S/RES/955\%20(1994)

Naciones Unidas, Estatuto de Roma de la Corte Penal Internacional, documento A/CONF.183/9, de 17 de julio de 1998, enmendado por los procés verbaux de 10 de noviembre de 1998, 12 de julio de 1999, 30 de noviembre de 1999, 8 de mayo de 2000, 17 de enero de 2001 y 16 de enero de 2002. Entró en vigor el 1 de julio de 2002. Disponible en: http://www.un.org/spanish/law/icc/statute/spanish/rome_statute(s).pdf

United Nations International Criminal Tribunal for the former Yugoslavia, ICTY, Updated Statute of the International Criminal Tribunal for the former Yugoslavia, adopted 25 May 1993 by Resolution 827, updated September 2009. Disponible en: http://www.icty.org/x/file/Legal\%20Library/Statute/statute_sept09_en.pdf

United States of America, United Kingdom, Soviet Union, and China, Moscow Conference, Joint Four-Nation Declaration, 30 October 1943. Disponible en: http://avalon.law.yale.edu/wwii/moscow.asp

United States, England, France and the Soviet Union, London Agreement, 8 August 1945. Disponible en: http://av alon.law.yale.edu/imt/imtchart.asp

\section{Normativa colombiana}

Colombia, Acto Legislativo 01 de 2017, por medio del cual se crea un título de disposiciones transitorias de la Constitución para la terminación del conflicto armado y la construcción de una paz estable y duradera y se dictan otras disposiciones, 50.196 Diario Oficial, 4 de abril de 2017. Disponible en: http://www.suin-juriscol.gov.co/ viewDocument.asp?ruta $=$ Acto $/ 30030428$

Colombia, Acto Legislativo 02 de 2017, por medio del cual se adiciona un artículo transitorio a la Constitución con el propósito de dar estabilidad y seguridad jurídica al acuerdo final para la terminación del conflicto y la construcción de una Paz Estable y Duradera, 50.230 Diario Oficial, 11 de mayo de 2017. Disponible en: http://www.suin-ju riscol.gov.co/viewDocument.asp?ruta $=$ Acto/30030560

Colombia, Constitución Política, segunda edición corregida, 116 Gaceta Constitucional, 20 de julio de 1991. Disponible en: http://www.secretariasenado.gov.co/senado/basedoc/constitucion_politica_1991.html

Colombia, Ley 599 de 2000, por la cual se expide el Código Penal, 44.097 Diario Oficial, 24 de julio de 2000. Disponible en: http://www.secretariasenado.gov.co/senado/basedoc/ley_0599_2000.html

Colombia, Ley 782 de 2002, por medio de la cual se prorroga la vigencia de la Ley 418 de 1997, prorrogada y modificada por la Ley 548 de 1999 y se modifican algunas de sus disposiciones, 45.043 Diario Oficial, 23 de diciembre de 2002. Disponible en: http://www.secretariasenado.gov.co/senado/basedoc/ley_0782_2002.html

Colombia, Ley 975 de 2005, por la cual se dictan disposiciones para la reincorporación de miembros de grupos armados organizados al margen de la ley, que contribuyan de manera efectiva a la consecución de la paz nacional y se dictan otras disposiciones para acuerdos humanitarios, 45.980 Diario Oficial, 25 de julio de 2005. Disponible en: http ://www.secretariasenado.gov.co/senado/basedoc/ley_0975_2005.html

Colombia, Ley 1738 de 2014, por medio de la cual se prorroga la Ley 418 de 1997, prorrogada y modificada por las Leyes 548 de 1999, 782 de 2002, 1106 de 2006 y 1421 de 2010, 49.369 Diario Oficial, 18 de diciembre de 2014. Disponible en: http://www.secretariasenado.gov.co/senado/basedoc/ley_1738_2014.html

Colombia, Ley 1820 de 2016, por medio de la cual se dictan disposiciones sobre amnistía, indulto y tratamientos penales especiales y otras disposiciones, 50.102 Diario Oficial, 30 de diciembre de 2016. Disponible en: http:// www.secretariasenado.gov.co/senado/basedoc/ley_1820_2016.html 


\section{Jurisprudencia internacional}

International Criminal Court, ICC, Prosecutor v. Jean-Pierre Bemba Gombo (ICC-01/05-01/08), PTC II, Decision Pursuant to Article 61(7)(a) and (b) of the Rome Statute, 15 June 2009. Disponible en: https://www.icc-cpi.i $\mathrm{nt} /$ pages/record.aspx?uri $=699541$

International Military Tribunal, IMT Nuremberg, The United States of America et al. v. Hermann Wilhelm Göring et al., en Trial of the Major War Criminals before the International Military Tribunal, Official Documents, Vol. 1, Judgement, 171-341 (Nuremberg, 1947). Disponible en: https://www.loc.gov/rr/frd/Military_Law/pdf/NT_ Vol-I.pdf

Military Tribunal III, The United States of America v. Alfried Felix Alwyn Krupp von Boblen und Halbach et al., en Trials of War Criminals before the Nuernberg Military Tribunals under Control Council Law No. 10, Case 10, Vol. IX, The Krupp Case (Government Printing Office, Washington, 1950). Disponible en: https://www.loc.g ov/rr/frd/Military_Law/NTs_war-criminals.html, https://www.loc.gov/rr/frd/Military_Law/pdf/NT_war-c riminals_Vol-IX.pdf

Military Tribunal IV, The United States of America v. Ernst von Weizsaecker et al., en Trials of War Criminals before the Nuernberg Military Tribunals under Control Council Law No. 10, Case 11, Vol. XII, The Ministries Case (Government Printing Office, Washington, 1952). Disponible en: https://www.loc.gov/rr/frd/Military_Law/ NTs_war-criminals.html, https://www.loc.gov/rr/frd/Military_Law/pdf/NT_war-criminals_Vol-XII.pdf

Military Tribunal IV, The United States of America v. Ernst von Weizsaecker et al., en Trials of War Criminals before the Nuernberg Military Tribunals under Control Council Law No. 10, Case 11, Vol. XIV, The Ministries Case (Government Printing Office, Washington, 1952). Disponible en: https://www.loc.gov/rr/frd/Military_Law/ NTs_war-criminals.html, https://www.loc.gov/rr/frd/Military_Law/pdf/NT_war-criminals_Vol-XIV.pdf

Military Tribunal IV, The United States of America v. Friedrich Flick et al., en Trials of War Criminals before the Nuernberg Military Tribunals under Control Council Law No. 10, Case 5, Vol. VI, The Flick Case (Government Printing Office, Washington, 1952). Disponible en: https://www.loc.gov/rr/frd/Military_Law/NTs_war-crim inals.html, https://www.loc.gov/rr/frd/Military_Law/pdf/NT_war-criminals_Vol-VI.pdf

Military Tribunal VI, The United States of America v. Carl Krauch et al., en Trials of War Criminals before the Nuernberg Military Tribunals under Control Council Law No. 10, Case 6, Vol. VII, The I. G. Farben Case (Government Printing Office, Washington, 1953). Disponible en: https://www.loc.gov/rr/frd/Military_Law/NTs_war-crim inals.html, https://www.loc.gov/rr/frd/Military_Law/pdf/NT_war-criminals_Vol-VII.pdf

Military Tribunal VI, The United States of America v. Carl Krauch et al., Trials of War Criminals before the Nuernberg Military Tribunals under Control Council Law No. 10, Case 6, Vol. VIII, The I. G. Farben Case (Government Printing Office, Washington, 1952). Disponible en: https://www.loc.gov/rr/frd/Military_Law/ NTs_war-criminals.html, https://www.loc.gov/rr/frd/Military_Law/pdf/NT_war-criminals_Vol-VIII.pdf

United Nations International Criminal Tribunal for Rwanda, UNICTR, Prosecutor v. Alfred Musema (Case No. ICTR-96-13-A), Trial Chamber I, TC I, Judgement and Sentence, 27 January 2000. Disponible en: http://unic tr.irmct.org/sites/unictr.org/files/case-documents/ictr-96-13/trial-judgements/en/000127.pdf

United Nations International Criminal Tribunal for Rwanda, UNICTR, Prosecutor v. Elizaphan and Gérard Ntakirutimana (Cases No. ICTR-96-10 \& ICTR-96-17-T), Trial Chamber I, TC I, Judgement and Sentence, 21 February 2003. Disponible en: http://unictr.irmct.org/sites/unictr.org/files/case-documents/ictr-96-17/tr ial-judgements/en/030221.pdf

United Nations International Criminal Tribunal for Rwanda, UNICTR, Prosecutor v. Ferdinand Nabimana, Jean Bosco-Barayagwiza and Hassan Ngeze (Case No. ICTR-99-52-T), Trial Chamber I, TC I, Judgement and Sentence, 3 December 2003. Disponible en: http://unictr.irmct.org/sites/unictr.org/files/case-documents/ictr -99-52/trial-judgements/en/031203.pdf

United Nations International Criminal Tribunal for Rwanda, UNICTR, Prosecutor v. Ferdinand Nabimana, Jean Bosco-Barayagwiza and Hassan Ngeze (Case No. ICTR-99-52-A), Appeals Chamber, AC, Judgement, 28 November 2007. Disponible en: http://unictr.irmct.org/sites/unictr.org/files/case-documents/ictr-99-52/app eals-chamber-judgements/en/071128.pdf 
United Nations International Criminal Tribunal for Rwanda, UNICTR, Prosecutor v. Kayishema and Ruzindana (Case No. ICTR-95-1-T), Trial Chamber II, TC II, Judgement, 21 May 1999. Disponible en: http://unictr.irm ct.org/sites/unictr.org/files/case-documents/ictr-95-1/trial-judgements/en/990521.pdf

United Nations International Criminal Tribunal for Rwanda, UNICTR, Prosecutor v. Ndahimana (Case No. ICTR-01-68-T), Trial Chamber II, TC II, Judgement and Sentence, 30 December 2011. Disponible en: http:/ /unictr.irmct.org/sites/unictr.org/files/case-documents/ictr-01-68/trial-judgements/en/111230.pdf

United Nations International Criminal Tribunal for Rwanda, UNICTR, Prosecutor v. Ngirabatware (Case No. ICTR-99-54-T), Trial Chamber II, TC II, 20 December 2012. Disponible en: http://unictr.irmct.org/sites/un ictr.org/files/case-documents/ictr-99-54/trial-judgements/en/121220.pdf

United Nations International Criminal Tribunal for the former Yugoslavia, ICTY, Prosecutor v. Blaškić (Case No. IT-95-14-A), Appeals Chamber, AC, Judgement, 29 July 2004. Disponible en: http://www.icty.org/x/cases/b laskic/acjug/en/bla-aj040729e.pdf

United Nations International Criminal Tribunal for the former Yugoslavia, ICTY, Prosecutor v. Brdanin (Case No. IT-99-36-A), Appeals Chamber, AC, Judgement, 3 April 2007. Disponible en: http://www.icty.org/x/cases/b rdanin/acjug/en/brd-aj070403-e.pdf

United Nations International Criminal Tribunal for the former Yugoslavia, ICTY, Prosecutor v. Delalić et al. (Case No. IT-96-21-T), Trial Chamber, TC, Judgement, 16 November 1998. Disponible en: http://www.icty.org/x/case s/mucic/tjug/en/981116_judg_en.pdf

United Nations International Criminal Tribunal for the former Yugoslavia, ICTY, Prosecutor v. Furundžija (Case No. IT-95-17/1-T), Trial Chamber, TC, Judgement, 10 December 1998. Disponible en: http://www.icty.org/x/ca ses/furundzija/tjug/en/fur-tj981210e.pdf

United Nations International Criminal Tribunal for the former Yugoslavia, ICTY, Prosecutor v. Karadžić (Case No. IT-95-5/18-T), Appeals Chamber, AC, Judgement, 24 March 2016. Disponible en: http://www.icty.org/x/ cases/karadzic/tjug/en/160324_judgement.pdf

United Nations International Criminal Tribunal for the former Yugoslavia, ICTY, Prosecutor v. Mrkšić et al. (Case No. IT-95-13/1-A), Appeals Chamber, AC, Judgement, 5 May 2009. Disponible en: http://www.icty.org/x/cases/ mrksic/acjug/en/090505.pdf

United Nations International Criminal Tribunal for the former Yugoslavia, ICTY, Prosecutor v. Tadić (Case No. IT-94-1-T), Trial Chamber, TC, Opinion and Judgement, 7 May 1997. Disponible en: http://www.icty.org/x /cases/tadic/tjug/en/tad-tsj70507JT2-e.pdf

United Nations International Criminal Tribunal for the former Yugoslavia, ICTY, Prosecutor v. Tadić (Case No. IT-94-1-A), AC, Judgement, 15 July 1999. Disponible en: http://www.icty.org/x/cases/tadic/acjug/en/tad-aj9 90715e.pdf [http://www.icty.org/x/cases/tadic/acjug/en/tad-corj991119e.pdf]

United Nations International Criminal Tribunal for the former Yugoslavia, ICTY, Prosecutor v. Vasiljević (Case No. IT-98-32-A), Appeals Chamber, AC, Judgement, 25 February 2004. Disponible en: http://www.icty.org/x/ca ses/vasiljevic/acjug/en/val-aj040225e.pdf

United Nations International Criminal Tribunal for the former Yugoslavia, ICTY, Prosecutor v. Vidoje Blagojević and Dragan Jokić (Case No. IT-02-60-A), Appeals Chamber, AC, Judgement, 9 May 2007. Disponible en: http://w ww.icty.org/x/cases/blagojevic_jokic/acjug/en/blajok-jud070509.pdf

United Nations Special Court for Sierra Leone, SCSL, Prosecutorv. Brima et al. (Case No. SCSL-2004-16-A), Appeals Chamber, AC, Judgement, 22 February 2008. Disponible en: http://www.rscsl.org/Documents/Transcripts/A FRC/AFRC-022208.PDF

\section{Jurisprudencia colombiana}

Colombia, Corte Constitucional, sentencia C-370-06, 18 de mayo de 2006, magistrados ponentes Manuel José Cepeda-Espinosa, Jaime Córdoba-Triviño, Rodrigo Escobar-Gil, Marco Gerardo Monroy-Cabra, Álvaro Tafur- 
Galvis, Clara Inés Vargas-Hernández. Disponible en: http://www.corteconstitucional.gov.co/relatoria/2006/C $-370-06 . h \mathrm{tm}$

Colombia, Corte Constitucional, sentencia C-674-17, 14 de noviembre de 2017, magistrado sustanciador Luis Guillermo Guerrero-Pérez. Disponible en: http://www.corteconstitucional.gov.co/relatoria/2017/c-674-17.ht $\mathrm{m}$

Colombia, Corte Suprema de Justicia, CSJ, Sala de Casación Penal, sentencia del 25 de abril de 2007, radicado 26617. Colombia, Corte Suprema de Justicia, CSJ, Sala de Casación Penal, sentencia del 10 de abril de 2008, radicado 29472.

Colombia, Corte Suprema de Justicia, CSJ, Sala de Casación Penal, sentencia del 21 de septiembre de 2009, radicado 32022.

Colombia, Corte Suprema de Justicia, CSJ, Sala de Casación Penal, sentencia del 7 de noviembre de 2012, radicado 39665.

Colombia, Corte Suprema de Justicia, CSJ, Sala de Casación Penal, sentencia del 15 de mayo de 2013, radicado 34320.

Colombia, Corte Suprema de Justicia, CSJ, Sala de Casación Penal, sentencia del 26 de febrero de 2014, radicado 42428.

Colombia, Corte Suprema de Justicia, CSJ, Sala de Casación Penal, sentencia del 9 de noviembre de 2016, radicado 44940.

Colombia, Corte Suprema de Justicia, CSJ, Sala de Casación Penal, sentencia del 8 de febrero de 2017, radicado 46099.

Colombia, Corte Suprema de Justicia, CSJ, Sala de Casación Penal, sentencia del 15 de marzo de 2017, radicado 48544.

Colombia, Corte Suprema de Justicia, CSJ, Sala de Casación Penal, decisión del 24 de julio de 2017, radicado 50458.

Colombia, Corte Suprema de Justicia, CSJ, Sala de Casación Penal, decisión del 24 de julio de 2017, radicado 49253.

Colombia, Corte Suprema de Justicia, CSJ, Sala de Casación Penal, decisión del 16 de agosto de 2017, radicado 50458.

\section{Documentos, informes, reportes}

Naciones Unidas, Comisión Preparatoria de la Corte Penal Internacional, Elementos de los Crimenes, PCNICC/2000/1/Add.2, 2 de noviembre de 2000. Disponible en: https://documents-dds-ny.un.org/doc/U NDOC/GEN/N00/724/30/PDF/N0072430.pdf?OpenElement

UNITED NATIONS WAR CRIMES COMMISSION, UNWCC, Law Reports of Trials of War Criminals, Vol. I (The United Nations War Crimes Commission by His Majesty's Stationery Office, London, 1947). Disponible en: https://www.loc.gov/rr/frd/Military_Law/pdf/Law-Reports_Vol-1.pdf

\section{Otros documentos}

COLOMBIA, CORTE CONSTITUCIONAL, comunicado de prensa No. 51, 11 de octubre de 2017, expediente RPZ-005. Disponible en: http://www.corteconstitucional.gov.co/comunicados/No.\%2051\%20comunicado\% 2011\%20de\%20octubre\%20de\%202017.pdf

COLOMBIA, FISCALÍA GENERAL DE LA NACIÓN, FGN, Directiva 001 del 4 de octubre de 2012, por medio de la cual se adoptan unos criterios de priorización de situaciones y casos, y se crea un nuevo sistema de investigación penal y de gestión de aquellos en la Fiscalía General de la Nación. Disponible en: https://www.fis calia.gov.co/colombia/wp-content/uploads/Directiva-N\%C2\%B0-0001-del-4-de-octubre-de-2012.pdf

COLOMBIA, FISCALÍA GENERAL DE LA NACIÓN, FGN, Dirección de Fiscalía Nacional Especializada de Justicia Transicional, Resolución Interlocutoria No. 002, Medellín (Antioquia), 12 de diciembre de 2016. Disponible en: http://www.derechos.org/nizkor/colombia/doc/accu1.html\#conc

COLOMBIA, FISCALÍA GENERAL DE LA NACIÓN, FGN, Financiación de empresas bananeras a grupos paramilitares es delito de lesa humanidad, 2 de febrero de 2017. Disponible en: https://www.fiscalia.gov.co/colo $\mathrm{mbia/noticias/financiacion-de-empresas-bananeras-a-grupos-paramilitares-es-delito-de-lesa-humanidad/}$

COLOMBIA, GOBIERNO NACIONAL \& FARC-EP, Acuerdo final para la terminación del conflicto y la construcción de una paz estable $y$ duradera, 24 de noviembre de 2016. Disponible 
en: http://www.altocomisionadoparalapaz.gov.co/procesos-y-conversaciones/Documentos\%20compartidos/2 4-11-2016NuevoAcuerdoFinal.pdf

COLOMBIA, JURISDICCIÓN ESPECIAL PARA LA PAZ, JEP, Anteproyecto, Guía de priorización de casos y situaciones en la Sala de Reconocimiento de Verdad, de Responsabilidad y de Determinación de Hechos y Conductas, mayo de 2018. Disponible en: https://www.jep.gov.co/Sala-de-Prensa/Documents/ANTEPROY ECTO\%20GU\%C3\%8DA\%20DE\%20PRIORIZACI\%C3\%93N\%20SRVR.pdf

INTERNATIONAL COMMISSION OF JURISTS, ICJ, Report of the International Commission of Jurists, Expert Legal Panel on Corporate Complicity in International Crimes, Corporate Criminality \& Legal Accountability Vol. 2: Criminal Law and International Crimes (International Commission of Jurists, ICJ, Geneva, 2008). Disponible en: http://www.refworld.org/pdfid/4a78423f2.pdf

UNITED NATIONS, GENERAL ASSEMBLY, Report of the Special Rapporteur on the Promotion of Truth, Justice, Reparation and Guarantees of Non-Recurrence, Pablo de Greiff (Doc. A/HRC/27/56), 27 August 2014. Disponible en: http://www.refworld.org/docid/543fbfe64.html

UNITED NATIONS, INTERNATIONAL LAW COMMISSION, ILC, Yearbook of the International Law Commission, 1996, Vol. II, Part Two (United Nations, New York, Geneva, 1998). Disponible en: http://legal.u n.org/ilc/publications/yearbooks/english/ilc_1996_v2_p2.pdf

UNITED NATIONS, SECURITY COUNCIL, Report of the Secretary-General pursuant to paragraph 5 of Security Council Resolution 955 (1994), 13 de febrero de 1995 (doc. S/1995/134). Disponible en: https://undocs.org/S /1995/134, http://francegenocidetutsi.org/sg-1995-134.pdf

VERDAD ABIERTA, Así investigan a financiadores del paramilitarismo, Verdadabierta, 7 de marzo de 2016. Disponible en: https://verdadabierta.com/asi-investigan-a-financiadores-del-paramilitarismo/

\section{Notas}

\section{* Artículo de investigación}

1 Al respecto, VOLKER NERLICH, Core Crimes and Transnational Business Corporations, 8 Journal of International Criminal Justice, 3, 895-908, 908 (2010). Según NERLICH, con razón, las prohibiciones que subyacen a los crímenes internacionales nucleares (core crimes) son vinculantes para las corporaciones transnacionales, a pesar de que no haya un tribunal internacional competente para juzgarlas. HARMEN VAN DER WILT, Corporate Criminal Responsibility for International Crimes: Exploring the Possibilities, 12 Chinese Journal of International Law, 1, 43-77, 46-49 (2013), en especial con relación a la propuesta presentada por Francia en la Conferencia de Roma. ALEXANDRA GARCÍA, Corporate Liability for International Crimes: A Matter of Legal Policy since Nuremberg, 24 Tulane Journal of International and Comparative Law, 97-129, 127 (2015-2016). GARCÍA sostiene que actualmente hay una tendencia a reconocer (en el ámbito nacional) la responsabilidad penal de las personas jurídicas, la cual en el futuro cercano puede derivar en una norma internacional de carácter consuetudinario.

2 El término "business leaders" ha sido definido de esta manera: HANS VEST, Business Leaders and the Modes of Individual Criminal Responsibility under International Law, 8 Journal of International Criminal Justice, 3, 851-872, 852 (2010): "Persons who de facto run a business corporation".

3 En este sentido, NORMAN FARRELL, Attributing Criminal Liability to Corporate Actors. Some Lessons from the International Tribunals, 8 Journal of International Criminal Justice, 3, 873-894, 876 (2010).

$4 \quad$ Ibíd., 877.

5 COLOMBIA, GOBIERNO NACIONAL \& FARC-EP, Acuerdo final para la terminación del conflicto y la construcción de una paz estable y duradera, 24 de noviembre de 2016. Apartado 5.1.2., punto 19: "Las secciones del Tribunal para la Paz, las Salas y la Unidad de Investigación y Acusación, al adoptar sus resoluciones o sentencias harán una calificación jurídica propia del Sistema respecto a las conductas objeto del mismo, calificación que se basará en el Código Penal colombiano y/o en las normas de Derecho Internacional [...] o Derecho Penal Internacional"; también Acto Legislativo 01 de 2017, artículo transitorio 5, inciso 7.

6 Según el artículo 10 LJP, esta se aplica a "miembros de grupos armados organizados al margen de la ley" que hayan cometido hechos delictivos "durante y con ocasión de la pertenencia a esos grupos, cuando no puedan ser beneficiarios de algunos de los mecanismos establecidos en la Ley 782 de 2002". Por ejemplo, de acuerdo con el artículo 19 de la Ley 782 (cuya vigencia inicial se ha 
prorrogado varias veces, por ejemplo, mediante la Ley 1738 de 2014) el Gobierno Nacional puede conceder el beneficio de indulto a quienes hayan sido condenados por hechos constitutivos de delito político. El tercer inciso de esta norma excluye de este beneficio a quienes sean responsables "de actos atroces de ferocidad o barbarie, terrorismo, secuestro, genocidio, homicidio cometido fuera de combate o colocando a la víctima en estado de indefensión”. La Ley de Justicia y Paz se expidió precisamente para tramitar mediante un proceso penal especial este tipo de casos.

7 Artículo 3 LJP sobre alternatividad; al respecto, Colombia, Corte Constitucional, sentencia C-370-06, 18 de mayo de 2006, magistrados ponentes Manuel José Cepeda-Espinosa, Jaime Córdoba-Triviño, Rodrigo Escobar-Gil, Marco Gerardo MonroyCabra, Álvaro Tafur-Galvis, Clara Inés Vargas-Hernández, apartados 1.2.21. y 1.2.22. de las consideraciones.

8 Artículo 7 LJP sobre derecho a la verdad.

9 Artículo 8 LJP sobre derecho a la reparación y artículo 11A (1) LJP sobre causales de terminación del proceso de Justicia y Paz.

$10 \mathrm{Al}$ respecto, se pueden consultar los informes del Centro Nacional de Memoria Histórica (CNMH) en http://www.cent rodememoriahistorica.gov.co/informes. Como ejemplos relevantes para este trabajo, CENTRO NACIONAL DE MEMORIA HISTÓRICA, CNMH, La maldita tierra. Guerrilla, paramilitares, mineras y conflicto armado en el departamento de Cesar, 50 ss. (CNMH, Bogotá, 2016). CNMH, Justicia y Paz. Tierras y territorios en las versiones de los paramilitares, 135-137 (CNMH, Bogotá, 2014).

11 La cifra exacta de compulsas de copias producto de las declaraciones de los jefes paramilitares no es del todo clara. Según Verdadabierta.com, portal de noticias especializado en temas del conflicto armado en Colombia, para 2015 se calculaba que había alrededor de 15.000, aunque después de un trabajo de depuración, la lista se redujo a 4.000. VERDAD ABIERTA, Así investigan a financiadores del paramilitarismo, Verdadabierta, 7 de marzo de 2016. Disponible en: https://verdadabierta.com/asi-investiga n-a-financiadores-del-paramilitarismo/

12 Por esta razón, en 2015, en la FGN se creó un grupo especializado de fiscales e investigadores dedicados a adelantar cerca de 50 investigaciones, agrupadas en distintas regiones de Colombia. Ibíd.

13 Denominado Sistema Integral de Verdad, Justicia, Reparación y No Repetición. COLOMBIA, GOBIERNO NACIONAL \& FARC-EP, Acuerdo final para la terminación del conflicto..., 124 ss.

14 Ibíd., 127 (apartado 5.1.)

15 Ibíd., (“[...] el Sistema pretende ser integral, para que las medidas logren un máximo de justicia y de rendición de cuentas $[\ldots] ")$.

16 El Acuerdo de Paz habla de "agentes del Estado", concepto más amplio que el de "miembros de la Fuerza Pública" definido en el artículo 216 de la Constitución Política de Colombia. Ibíd., 149 (apartado 5.1.2., punto 32).

17 Ibíd. ("También serán de competencia de la Jurisdicción Especial para la Paz las conductas de financiación o colaboración con los grupos paramilitares, o con cualquier actor del conflicto”).

18 La JEP está integrada, entre otros, por un Tribunal de Paz (conformado por tres secciones) y tres salas adicionales, las cuales resuelven asuntos preliminares. Además de la Sala de Reconocimiento de Verdad y Responsabilidad, también se encuentran la Sala de Amnistía e Indulto y la Sala de Definición de Situaciones Jurídicas. Sobre estos órganos y sus funciones, ibíd., 152 ss. (apartado 5.1.2.).

19 Ibíd., p. 154 (apartado 5.1.2., punto 48 (b) segundo párrafo).

20 Colombia, Corte Constitucional, sentencia C-674-17, 14 de noviembre de 2017, magistrado sustanciador Luis Guillermo Guerrero-Pérez, apartado 5.5.2.9. y 5.5.2.14 de las Consideraciones.

21 Ibíd.

22 Ibíd.

23 COLOMBIA, GOBIERNO NACIONAL \& FARC-EP, Acuerdo final para la terminación del conflicto..., 149 (apartado 5.1.2., punto 32). Adicionalmente, la conducta no debe ser producto de coacción y no debe existir una condena previa por los mismos hechos. Con relación a los crímenes de competencia de la JEP, el punto 9 (145, apartado 5.1.2.) del Acuerdo establece que esta ejercerá sus funciones "en especial respecto a conductas consideradas graves infracciones al Derecho Internacional Humanitario 
o graves violaciones de los Derechos Humanos". En este sentido, el punto 40 (151, apartado 5.1.2.) excluye la posibilidad de conceder la amnistía o cualquier otro beneficio por conductas que constituyan delitos de lesa humanidad, genocidio, crímenes de guerra, toma de rehenes u otra privación grave de la libertad, tortura, ejecuciones extrajudiciales, desaparición forzada, acceso carnal violento y otras formas de violencia sexual, sustracción de menores, desplazamiento forzado, además del reclutamiento de menores, "todo ello conforme a lo establecido en el Estatuto de Roma”. En consecuencia, en la JEP deberán ser juzgados quienes tengan responsabilidad por estas conductas. También ver los artículos 23 - parágrafo (a) —, 30 (1), 46 (1) y 47 Ley 1820 de 2016, mediante la cual se dictan disposiciones sobre amnistía, indulto y tratamientos penales especiales en desarrollo del Acuerdo de Paz.

24 Sobre este beneficio, ver los artículos 46, 47 y 48, Ley 1820 de 2016.

25 Ver nota 23.

26 Esta norma enuncia las funciones de la Sala de Definición de Situaciones Jurídicas de la JEP. El criterio "participación determinante" también aparece en los criterios de priorización diseñados y socializados por la Sala de Reconocimiento de Verdad. COLOMBIA, JURISDICCIÓN ESPECIAL PARA LA PAZ, JEP, Anteproyecto, Guía de priorización de casos y situaciones en la Sala de Reconocimiento de Verdad, de Responsabilidad y de Determinación de Hechos y Conductas, 9, mayo de 2018.

27 La referencia a estos casos no obedece (simplemente) a un interés "histórico", sino a los ámbitos normativos relevantes en la JEP y a sus sistemas de fuentes.

28 Allied Control Council, Control Council Law No. 10, Punishment of Persons Guilty of War Crimes, Crimes against Peace and against Humanity [Kontrollratsgesetz Nr. 10], 20 December 1945. Disponible en: http://avalon.law.yale.edu/imt/imt10.as $\mathrm{p}$

29 United States of America, United Kingdom, Soviet Union, and China, Moscow Conference, Joint Four-Nation Declaration, 30 October 1943. Disponible en: http://avalon.law.yale.edu/wwii/moscow.asp

30 United States, England, France and the Soviet Union, London Agreement, 8 August 1945. Disponible en: http://avalon. law.yale.edu/imt/imtchart.asp

31 La sentencia del Tribunal Penal Militar de Núremberg, TPM, contra Hermann Göring et al. fue proferida el 1 de octubre de 1946. International Military Tribunal, IMT Nuremberg, The United States of America et al. v. Hermann Wilhelm Göring et al., en Trial of the Major War Criminals before the International Military Tribunal, Official Documents, Vol. 1, Judgement, 171-341 (Nuremberg, 1947). Disponible en: https://www.loc.gov/rr/frd/Military_Law/pdf/NT_Vol-I.pdf

32 Military Tribunal IV, The United States of America v. Friedrich Flick et al., en Trials of War Criminals before the Nuernberg Military Tribunals under Control Council Law No. 10, Case 5, Vol. VI, The Flick Case, 3 ss. (Government Printing Office, Washington, 1952). Disponible en: https://www.loc.gov/rr/frd/Military_Law/NTs_war-criminals.html, https://www.loc.gov/ rr/frd/Military_Law/pdf/NT_war-criminals_Vol-VI.pdf

33 Ibíd., 3, 11 ss. (Indictment), 1187 ss. (Opinion and Judgment).

34 Ibíd., 3, 1223.

35 Ibíd., 1192.

36 Ibíd.

37 Ibíd., 1194-1202.

38 Ibíd.

39 Ibíd., 1202.

40 Ibíd., 1217.

41 Military Tribunal III, The United States of America v. Alfried Felix Alwyn Krupp von Boblen und Halbach et al., en Trials of War Criminals before the Nuernberg Military Tribunals under Control Council Law No. 10, Case 10, Vol. IX, The Krupp Case, 1 ss. (Government Printing Office, Washington, 1950). Disponible en: https://www.loc.gov/rr/frd/Military_Law/NTs_war-crim inals.html, https://www.loc.gov/rr/frd/Military_Law/pdf/NT_war-criminals_Vol-IX.pdf

42 Ibíd., 1. 
43 Ibíd., 1, 7 ss. (Indictment), 1327 ss. (Judgment), 1128-1129 (los cargos uno y cinco involucraban crímenes contra la paz y conspiración para cometerlos, pero por ausencia de material probatorio, el Tribunal los rechazó antes de proferir la sentencia).

44 Ibíd., 1449-1452.

45 Ibíd., 1448.

46 Ibíd.

47 El Tribunal cita la obra Corpus Juris Secundum, Volume 19, 363-364 (American Law Book Co., Brooklyn, New York, 1940).

48 Military Tribunal III, The United States of America v. Alfried Felix Alwyn Krupp von Boblen..., 1448 (1950).

49 Ibíd., 1449.

50 Military Tribunal VI, The United States of America v. Carl Krauch et al., en Trials of War Criminals before the Nuernberg Military Tribunals under Control Council Law No. 10, Case 6, Vol. VII, The I. G. Farben Case, 1 ss. (Government Printing Office, Washington, 1953). Disponible en: https://www.loc.gov/rr/frd/Military_Law/NTs_war-criminals.html, https://www.loc.gov/ rr/frd/Military_Law/pdf/NT_war-criminals_Vol-VII.pdf

51 También se formularon cargos por crímenes contra la paz y por pertenencia a una organización criminal, ibíd., 10 ss. (Indictment). Igualmente, Military Tribunal VI, The United States of America v. Carl Krauch et al., Trials of War Criminals before the Nuernberg Military Tribunals under Control Council Law No. 10, Case 6, Vol. VIII, The I. G. Farben Case, 1081 ss. (Opinion and Judgment), 1082-1083 (Government Printing Office, Washington, 1952). Disponible en: https://www.loc.gov/rr/frd/Milit ary_Law/NTs_war-criminals.html, https://www.loc.gov/rr/frd/Military_Law/pdf/NT_war-criminals_Vol-VIII.pdf

52 Military Tribunal VI, The United States of America v. Carl Krauch et al..., 1081 ss. (Opinion and Judgment), 1082-1083 (1952).

53 Military Tribunal VI, The United States of America v. Carl Krauch et al..., 51 ss. (1953).

54 Ibíd.

55 Military Tribunal VI, The United States of America v. Carl Krauch et al..., 1081 ss. (Opinion and Judgment), 1153 (1952).

56 Ibíd.

57 Ibíd., 1137.

58 Ibíd., 1140.

59 Ibíd., 1154.

60 Ibíd., 1154-1156.

61 Ibíd., 1158.

62 Este punto también se podría ilustrar con el caso de Karl Rasche y el Banco de Dresden discutido en el proceso llevado a cabo contra los ministerios del Gobierno Nacionalsocialista (Ministeries-case), también conocido en alemán como WilhelmstraßeProzess. Military Tribunal IV, The United States of America v. Ernst von Weizsaecker et al., en Trials of War Criminals before the Nuernberg Military Tribunals under Control Council Law No. 10, Case 11, Vol. XII, The Ministries Case, 1 ss. y 13 ss. (Government Printing Office, Washington, 1952). Disponible en: https:/www.loc.gov/rr/frd/Military_Law/NTs_war-criminals.html, https ://www.loc.gov/rr/frd/Military_Law/pdf/NT_war-criminals_Vol-XII.pdf. Military Tribunal IV, The United States of America v. Ernst von Weizsaecker et al., en Trials of War Criminals before the Nuernberg Military Tribunals under Control Council Law No. 10, Case 11, Vol. XIV, The Ministries Case, 308 ss. (Judgment), 852-855 (Government Printing Office, Washington, 1952). Disponible en: https://www.loc.gov/rr/frd/Military_Law/NTs_war-criminals.html, https://www.loc.gov/rr/frd/Military_Law /pdf/NT_war-criminals_Vol-XIV.pdf

63 Military Tribunal VI, The United States of America v. Carl Krauch et al..., 1169 (1952).

64 Ibíd., 1169.

65 Ibíd., 1170-1172. 
66 UNITED NATIONS WAR CRIMES COMMISSION, UNWCC, Law Reports of Trials of War Criminals, Vol. I, 93 ss. (The United Nations War Crimes Commission by His Majesty's Stationery Office, London, 1947). Disponible en: https://www .loc.gov/rr/frd/Military_Law/pdf/Law-Reports_Vol-1.pdf

67 El fundamento normativo para la imputación de este cargo era el artículo 46 de las Regulaciones de La Haya de 1907, ibíd., 94.

68 Ibíd., 93.

69 Ibíd., 96-97, 102.

70 Ibíd., 103.

71 Ibíd.

72 Ibíd., 102.

73 El TPIR fue creado mediante la Resolución 955 del 8 de noviembre de 1994 por el Consejo de Seguridad de Naciones Unidas. $\mathrm{Al}$ respecto, UNITED NATIONS, SECURITY COUNCIL, Report of the Secretary-General pursuant to paragraph 5 of Security Council Resolution 955 (1994), 13 de febrero de 1995 (doc. S/1995/134), párr. 1 ss., 6 ss. (fundamento normativo de su creación), 10 ss. (competencia material del Tribunal). El TPIR profirió su última sentencia de primera instancia el 20 de diciembre de 2012 en el caso Ngirabatware. El trabajo posterior se concentró en resolver asuntos pendientes de apelación, lo cual ha sido asumido actualmente por el International Residual Mechanism for Criminal Tribunals. Al respecto, se puede consultar la página web oficial del mecanismo residual: http://unictr.unmict.org/en/tribunal

74 UNICTR, Prosecutor v. Alfred Musema (Case No. ICTR-96-13-A), Trial Chamber I, TC I, Judgement and Sentence, 27 January 2000, par. 12-13. Disponible en: http://unictr.irmct.org/sites/unictr.org/files/case-documents/ictr-96-13/trial-judgem ents/en/000127.pdf

75 Por ejemplo, en varios ataques realizados en la región de Bisesero entre el 9 de abril y el 30 de junio de 1994, ibíd., 362 ss.

76 Artículo 6 (1) Estatuto del TPIR: "A person who planned, instigated, ordered, committed or otherwise aided and abetted in the planning, preparation or execution".

77 Artículo 6 (3) Estatuto del TPIR: "The fact that any of the acts referred to in articles 2 to 4 of the present Statute was committed by a subordinate does not relieve his or her superior of criminal responsibility [...]". Con relación a los hechos en los que participó el acusado, UNICTR, Prosecutor v. Alfred Musema (Case No. ICTR-96-13-A)..., 27 January 2000, par. 892, 898, 906, 909, 915, 920, 925 .

78 UNICTR, Prosecutor v. Alfred Musema (Case No. ICTR-96-13-A)..., 27 January 2000, par. 128, 136. ICTY, Prosecutor v. Delalic et al. (Case No. IT-96-21-T), Trial Chamber, TC, Judgement, 16 November 1998, par. 356. Disponible en: http://www.ic ty.org/x/cases/mucic/tjug/en/981116_judg_en.pdf. UNICTR, Prosecutor v. Kayishema and Ruzindana (Case No. ICTR-95-1T), Trial Chamber II, TC II, Judgement, 21 May 1999. Disponible en: http://unictr.irmct.org/sites/unictr.org/files/case-docume nts/ictr-95-1/trial-judgements/en/990521.pdf, par. 213 ss. La responsabilidad penal (por omisión) con fundamento en la posición de superior jerárquico de "jefes" no militares fue prevista expresamente en el artículo 28 (b) del Estatuto de Roma, ER. Al respecto, OTTO TRIFFTERER \& ROBERTA ARNOLD, Article 28, Responsibility of Commanders and Other Superiors, en The Rome Statute of the International Criminal Court. A Commentary, 1101-1103 (OTTO TRIFFTERER \& KAI AMBOS, eds., C. H. Beck, Hart, Nomos, München, 2016). WILLIAM SCHABAS, The International Criminal Court. A Commentary of the Rome Statute, 612-613 (Oxford University Press, Oxford, 2016).

79 UNICTR, Prosecutor v. Alfred Musema (Case No. ICTR-96-13-A)..., 27 January 2000, par. 135 ("the superior's actual or formal power of control over his subordinates remains a determining factor in charging civilians with superior responsibility"). Además, la sentencia en contra: UNICTR, Prosecutor v. Elizaphan and Gérard Ntakirutimana (Cases No. ICTR-96-10 \& ICTR-96-17-T), Trial Chamber I, TC I, Judgement and Sentence, 21 February 2003, par. 431-432, 919. Disponible en: http: //unictr.irmct.org/sites/unictr.org/files/case-documents/ictr-96-17/trial-judgements/en/030221.pdf. Gérard Ntakirutimana se desempeñaba como médico en el hospital de Mugonero, en donde tuvo lugar una de las masacres que se cometieron en Ruanda en 1994. Gérard Ntakirutimana fue absuelto de los cargos presentados con base en el artículo 6 (3) del Estatuto del TPIR, debido a que no se probó que hubiera tenido control efectivo, especialmente sobre Mathias Ngirinshuti (director del hospital), a pesar de que, según la acusación, entre abril y julio de 1994 estuvo a cargo (de facto) de esa institución. 
Ibíd., par. 894, 899, 905, 914, 919, 924.

82 Hassan Ngeze fue fundador y editor en jefe del periódico Kangura, así como miembro fundador del partido Coalition for the Defence of the Republic, CDR. Este fue condenado, entre otras razones, con base en las publicaciones que aparecieron en ese periódico, en las que de hecho él mismo participó. Debido a que la Cámara de Juzgamiento no discute la posición de superior de este acusado, aquí no se hace referencia a esta parte de la sentencia. Sobre Hassan Ngeze, UNICTR, Prosecutor $v$. Ferdinand Nahimana, Jean Bosco-Barayagwiza and Hassan Ngeze (Case No. ICTR-99-52-T), Trial Chamber I, TC I, Judgement and Sentence, 3 December 2003, par. 7, 10, 122 ss., 977-978, 1055, 1084. Disponible en: http://unictr.irmct.org/sites/unictr.or $\mathrm{g} /$ files/case-documents/ictr-99-52/trial-judgements/en/031203.pdf

\section{Ibíd., par. 5.}

84 Ibíd., par. 8.

85 Ibíd., par. 6.

86 Ibíd., par. 10.

87 Ibíd., par. 970 ("They represented the radio at the highest level in meetings with the Ministry of Information; they controlled the finances of the company; and they were both members of the Steering Committee, which functiones in effect as a board of directors for RTLM" [Radio Télévision Libre des Mille Collines, Radio Televisión Libre de las Mil Colinas, RTLM]).

88 Ibíd., par. 973-977.

89 Ibíd., par. 970.

90 Ibíd., par. 972.

91 UNICTR, Prosecutor v. Ferdinand Nabimana, Jean Bosco-Barayagwiza and Hassan Ngeze (Case No. ICTR-99-52-A), Appeals Chamber, AC, Judgement, 28 November 2007, par. 594. Disponible en: http://unictr.irmct.org/sites/unictr.org/files/c ase-documents/ictr-99-52/appeals-chamber-judgements/en/071128.pdf

92 Ibíd., par. 599.

93 Ibíd., par. 635.

94 Ibíd., par. 487, 667.

95 Ibíd., par. 485. La Sala de Apelaciones se basa aquí en ICTY, Prosecutor v. Vidoje Blagojević and Dragan Jokić (Case No. IT-02-60-A), Appeals Chamber, AC, Judgement, 9 May 2007, par. 280-282. Disponible en: http://www.icty.org/x/cases/blagoje vic_jokic/acjug/en/blajok-jud070509.pdf ("the Appeals Chamber confirms that superior responsibility under Article 7(3) of the Statute [ICTY] encompasses all forms of criminal conduct by subordinates").

96 FARRELL identifica, en términos generales, tres tipos de casos: (i) comisión directa de crímenes por parte de las empresas, (ii) contribución a la perpetración de crímenes por parte de otros, por ejemplo, al proporcionar armas a grupos o gobiernos de los que se sabe que están envueltos en la comisión de crímenes internacionales y (iii) "participación" tangencial al desarrollar actividades o negocios en áreas afectadas por este tipo de hechos. NORMAN FARRELL, Attributing Criminal Liability to Corporate Actors..., 873-894, 873-874 (2010). Con relación a Colombia, SÁNCHEZ identifica tres tipos de situaciones que darían lugar a distintas formas de responsabilidad, NELSON CAMILO SÁNCHEZ, Corporate Accountability, Reparations, and Distributive Justice in Post-Conflict Societies, en Corporate Accountability in the Context of Transitional Justice, 114-131, 123-128 (SABINE MICHALOWSKI, ed., Routledge, London, New York, 2013).

$97 \mathrm{Al}$ respecto, ARTHUR KAUFMANN, Das Schuldprinzip. Eine strafrechtlich-rechtsphilosophische Untersuchung, 208 (Carl Winter Universitätsverlag, Heidelberg, 1976): "Strafe ist die vierdiente Antwort auf die Schuld". UWE MURMANN, Grundkurs Strafrecht:Allgemeiner Teil, Tötungsdelikte, Körperverletzungsdelikte, 79 (C. H. Beck, München, 2015). Con relación al DPI, KAI AMBOS, Treatise on International Criminal Law, Volume I: Foundations and General Part, 93-95 (Oxford University Press, Oxford, 2013). En este sentido, el TPM de Núremberg afirmó: "one of the most important [legal principles] is that criminal guilt is personal, and that mass punishments should be avoided". International Military Tribunal, IMT Nuremberg, The United States of America et al. v. Hermann Wilhelm Göring et al..., 256 (1947).

98 Los crímenes internacionales constituyen formas de "macrocriminalidad". Al respecto, el clásico de HERBERT JÄGER, Makrokriminalität \# Studien zur Kriminologie kollektiver Gewalt, 12 (Suhrkamp, Frankfurt am Main, 1989): "das individuelle 
Handeln nicht als isolierte Tat [...] sondern nur Teil eines kollektiven Aktionszusammenhangs". KAI AMBOS, Treatise on International Criminal Law, Volume I..., 84-86 (2013). STEFANIE BOCK, Zurechnung im Völkerstrafrecht, 7-8 Zeitschrift für Internationale Strafrechtsdogmatik, ZIS, 410-427, 411 (2017).

99 La definición actual de los crimenes de lesa humanidad exige un ataque generalizado o sistemático contra la población civil. Un ataque de este tipo supone, por un lado, un número amplio de víctimas y, por otro, cierto nivel de organización (artículo 7 (1) ER). KAI AMBOS, Treatise on International Criminal Law, Volume II: The Crimes and Sentencing, 59-63 (Oxford University Press, Oxford, 2014). De ahí que el artículo 7 (2) ER defina el ataque generalizado contra la población civil como "una línea de conducta que implique la comisión múltiple de actos mencionados en el párrafo 1 contra una población civil, de conformidad con la política de un Estado o de una organización de cometer ese ataque o para promover esa política" (cursivas por fuera del texto original). Algo parecido ocurre con el genocidio, ya que en el documento Elementos de los Crímenes se ha incluido como elemento contextual "[q]ue la conducta haya tenido lugar en el contexto de una pauta manifiesta de conducta similar [...]" (AMBOS, 17-18). Con relación a los crimenes de guerra, aunque la definición de estos no incluye un elemento contextual similar al de los crimenes de lesa humanidad, al menos en el artículo 8 (1) ER se ha incluido como criterio jurisdiccional para la Corte Penal Internacional (CPI) la expresión "como parte de un plan o política o como parte de la comisión en gran escala" (AMBOS, 118-119). Algo similar ocurre con el crimen de agresión, para cuya consumación se requiere, según el artículo 8bis (1) ER, actos de agresión que por sus características, gravedad y escala constituyan una violación manifiesta de la Carta de las Naciones Unidas (AMBOS, 198-199).

100 KLAUS MARXEN, Beteiligung an schwerem systematischen Unrecht - Bemerkungen zu einer völkerstrafrechtlichen Straftatlehre, en Aufgeklärte Kriminalpolitik oder Kampf gegen das Böse?, Band III, Makrokriminalität, 220-236, 234-235 (KLAUS LÜDERSSEN, ed., Nomos, Baden-Baden, 1998). MARXEN advirtió sobre este problema al proponer los fundamentos de una teoría de la imputación para los crímenes internacionales: "Wie läßt sich die Mitwirkung des einzelnen an einem Verbrechenskomplex [...] sachgerecht durch zurechnende Begriffe erfassen?”.

101 En general, sobre este tema en DPI, HANS VEST, Völkerrechtsverbrecher verfolgen. Ein abgestuftes Mehrebenenmodell systemischer Tatherrschaft, 195-204 (Stämpfli Verlag AG, Bern, 2011). KAI AMBOS, Treatise on International Criminal Law, Volume I, 163 ss. (2013).

102 Según el artículo 2 (3) (d) del Draft Code of Crimes against the Peace and Security of Mankind de la Comisión de Derecho Internacional de NU (ILC por sus siglas en inglés), para ser cómplice se tendría que contribuir directa y sustancialmente ("directly and substantially”) a la comisión del crimen. UNITED NATIONS, INTERNATIONAL LAW COMMISSION, ILC, Yearbook of the International Law Commission, 1996, Vol. II, Part Two, 18 (United Nations, New York, Geneva, 1998). De acuerdo con la ILC, esto significa que el aporte debe facilitar la comisión del crimen en alguna forma significativa, por ejemplo, cuando se proveen los medios para cometerlo, ibíd., 21. En este sentido, en el contexto de los tribunales penales internacionales ad hoc se afirmó que el aporte debía haber tenido un "efecto sustancial" sobre la perpetración de los crímenes ("a substantial effect upon the perpetration of the crime"). ICTY, Prosecutor v. Karadžić (Case No. IT-95-5/18-T), Appeals Chamber, AC, Judgement, 24 March 2016, par. 575. Disponible en: http://www.icty.org/x/cases/karadzic/tjug/en/160324_judgement.pdf. ICTY, Prosecutor v. Blaskicic (Case No. IT-95-14-A), Appeals Chamber, AC, Judgement, 29 July 2004, par. 48. Disponible en: http://www.icty.o $\mathrm{rg} / \mathrm{x} /$ cases/blaskic/acjug/en/bla-aj040729e.pdf. ICTY, Prosecutor v. Vasiljevic (Case No. IT-98-32-A), Appeals Chamber, AC, Judgement, 25 February 2004, par. 102 (i). Disponible en: http://www.icty.org/x/cases/vasiljevic/acjug/en/val-aj040225e.pdf. UNICTR, Prosecutor v. Ngirabatware (Case No. ICTR-99-54-T), Trial Chamber II, TC II, 20 December 2012, par. 1294. UNICTR, Prosecutor v. Ndabimana (Case No. ICTR-01-68-T), Trial Chamber II, TC II, Judgement and Sentence, 30 December 2011, par. 723. Disponible en: http://unictr.irmct.org/sites/unictr.org/files/case-documents/ictr-01-68/trial-judgements/en/1 11230.pdf. El artículo 25 (3) (c) ER no hace referencia expresa a la relevancia del aporte; sin embargo, se ha afirmado que este elemento en todo caso encuentra fundamento en el Estatuto. En este sentido, HANS VEST, Völkerrechtsverbrecher verfolgen. Ein abgestuftes Mebrebenenmodell systemischer Tatherrschaft, 199 (2011) (por ejemplo, con base en el artículo 17 (1) (d) ER). Para VEST, el efecto sustancial no se debe predicar con relación al resultado, sino a la forma de consumación; también ver KAI AMBOS, Treatise on International Criminal Law, Volume I, 164-166 (2013) (llama la atención sobre la necesidad de tener en cuenta la teoría del aumento del riesgo, 165).

103 En el contexto de los tribunales ad hoc se afirmó que para la responsabilidad penal a título de complicidad no era necesario que el aporte tuviera esta condición. Por ejemplo, ICTY, Prosecutor v. Furundžija (Case No. IT-95-17/1-T), Trial Chamber, TC, Judgement, 10 December 1998, par. 233 (haciendo referencia al proceso Zyklon B). Disponible en: http://www.icty.org/x/cas es/furundzija/tjug/en/fur-tj981210e.pdf. UNICTR, Prosecutor v. Kayishema and Ruzindana (Case No. ICTR-95-1-T), Trial Chamber II, TC II, Judgement, 21 May 1999, par. 201. Crítico sobre la fórmula conditio sine qua non como pseudojustificación en casos de causalidad alternativa o hipotética (relevantes en el DPI), UWE MURMANN, Problems of Causation with Regard to (Potential) Actions of Multiple Protagonists, 12 Journal of International Criminal Justice, 2, 283-294, 288 (2014). 
104 En este sentido, STEFANIE BOCK, Zurechnung im Völkerstrafrecht, 410-427, 424, 427 (2017).

$105 \mathrm{Al}$ respecto, la Directiva 001 del 4 de octubre de 2012 de la FGN establece criterios para la priorización de casos en la investigación criminal en Colombia y hace referencia a los "máximos responsables y sus colaboradores". COLOMBIA, FISCALÍA GENERAL DE LA NACIÓN, FGN, Directiva 001 del 4 de octubre de 2012, por medio de la cual se adoptan unos criterios de priorización de situaciones y casos, y se crea un nuevo sistema de investigación penal y de gestión de aquellos en la Fiscalía General de la Nación, 29. Disponible en: https://www.fiscalia.gov.co/colombia/wp-content/uploads/Directiva-N\%C2\%B0-000 1-del-4-de-octubre-de-2012.pdf. Asimismo, UNITED NATIONS, GENERAL ASSEMBLY, Report of the Special Rapporteur on the Promotion of Truth, Justice, Reparation and Guarantees of Non-Recurrence, Pablo de Greiff(Doc. A/HRC/27/56), 27 August 2014. Disponible en: http://www.refworld.org/docid/543fbfe64.html. Este informe recoge varias experiencias de priorización de casos y sistematiza los criterios utilizados en los ámbitos nacional e internacional (párr. 59: "The term \#most responsible\# has been commonly defined as encompassing individuals who are in senior leadership positions or a position of influence to plan, order or incite serious crimes").

106 Similar, UNITED NATIONS, INTERNATIONAL LAW COMMISSION, ILC, Yearbook of the International Law Commission, 1996..., 21 (1998): "an individual who provides some type of assistance to another individual without knowing that this assistance will facilitate the commission of a crime would not be held accountable under subparagraph (d)". United Nations Special Court for Sierra Leone, SCSL, Prosecutor v. Brima et al. (Case No. SCSL-2004-16-A), Appeals Chamber, AC, Judgement, 22 February 2008, par. 242-243. Disponible en: http://www.rscsl.org/Documents/Transcripts/AFRC/AFRC-0222 08.PDF (el acusado debe saber que sus actos muy probablemente ayudarían a la comisión de un crimen, sin que sea necesario el conocimiento de un hecho delictivo específico). También ICTY, Prosecutor v. Furundžija (Case No. IT-95-17/1-T)..., par. 246. ICTY, Prosecutor v. Blaškić (Case No. IT-95-14-A)..., 45-51. Al respecto, ANTONIO CASSESE \& PAOLA GAETA, Cassese's International Criminal Law, 193-194 (Oxford University Press, Oxford, 2013): "It is sufficient that he has knowledge that the principal is committing the crime". Sin embargo, ha existido controversia a partir de la decisión de la Cámara de Apelaciones del TPIY, según la cual el aporte del cómplice debe estar "específicamente dirigido" ("specifically directed") a apoyar la comisión del crimen (ICTY, Prosecutorv. Tadic (Case No. IT-94-1-A), AC, Judgement, 15 July 1999, par. 229. Disponible en: http://www.icty. org/x/cases/tadic/acjug/en/tad-aj990715e.pdf [http://www.icty.org/x/cases/tadic/acjug/en/tad-corj991119e.pdf]). Al respecto y rechazando esta postura, ROBERT CRYER, HÅKAN FRIMAN, DARRYL ROBINSON \& ELIZABETH WILMSHURST, An Introduction to International Criminal Law and Procedure, 372-374 (Cambridge University Press, Cambridge, 2014). Por otro lado, al parecer en el ER, mediante la expresión “[c]on el propósito de facilitar la comisión” del artículo 25 (3) (c), se incluyó como elemento subjetivo de la complicidad un estándar más alto que el solo conocimiento. Al respecto, STEFANIE BOCK, Zurechnung im Völkerstrafrecht, 410-427, 423-424 (2017). KAI AMBOS, Treatise on International Criminal Law, Volume I, 165-166 (2013). Sin embargo, el artículo 253 (d) del ER también criminaliza las contribuciones a hechos grupales, para lo cual el conocimiento de la intención criminal del grupo es suficiente. Al respecto, KYUNG-GYU PARK, Rechtsnatur, konkrete Voraussetzungen und Legitimität der Beteiligungsform gemäß Art. 25 Abs. 3 lit. (d) IStGH-Statut, 191-193 (Duncker \& Humblot, Berlin, 2016). Sobre el tipo de contribución que exige esta forma de participación, KAI AMBOS, The ICC and Common Purpose - What Contribution is Required under Article 25(3)(d)?, en The Law and Practice of the International Criminal Court, 592-607 (CARSTEN STAHN, ed., Oxford University Press, Oxford, 2015).

107 El artículo 25 (3) ER diferencia entre perpetración principal o autoría (artículo 25 (3) (a) ER) y perpetración accesoria o participación, esta última incluye el hecho de ordenar, proponer o inducir la consumación del crimen (artículo 25 (3) (b) ER), así como la complicidad/encubrimiento (artículo 25 (3) (c) ER) y la contribución a un hecho grupal (artículo 25 (3) (d) ER). Sobre esta base, la CPI ha acogido el "dominio del hecho" como criterio para diferenciar entre autoría y participación, y para configurar la coautoría exige la existencia de un acuerdo o plan común entre dos o más personas, la realización de una contribución "esencial” — la cual no supone intervenir directamente en la etapa de consumación- por parte de los coautores y, como elemento subjetivo, la intención en el sentido del artículo 30 ER. Al respecto, KAI AMBOS, Treatise on International Criminal Law, Volume I, 149-154 (2013). STEFANIE BOCK, Zurechnung im Völkerstrafrecht, 410-427, 418-419 (2017) (con referencias jurisprudenciales en los pies de página 94 y 95); discutiendo esta "importación" de la doctrina alemana JENS DAVID OHLIN, Co-Perpetration, German Dogmatik or German Invasion?, en The Law and Practice of the International Criminal Court, 517-537 (CARSTEN STAHN, ed., Oxford University Press, Oxford, 2015). En el contexto de los tribunales ad hoc, la existencia de un acuerdo común y la realización de un aporte dirigido a su consecución darían lugar a la figura de la empresa criminal común (ECC), la cual en líneas generales, al menos en su forma básica (ECC I), es equivalente a la coautoría (STEFANIE BOCK, Zurechnung im Völkerstrafrecht, 410-427, 416-417 (2017)). Al respecto, ANTONIO CASSESE \& PAOLA GAETA, Cassese's International Criminal Law, 163-175 (2013).

108 El estándar incluido en el artículo 25 (3) (c) ER (ver nota 106), al exigir más que el conocimiento, parece exigir en el cómplice la intención concreta de que los crímenes se cometan, lo cual restringiría el ámbito de la complicidad. Esto resulta problemático, si se tiene en cuenta que, en ocasiones, el aporte realizado por el cómplice en sí mismo considerado puede no ser criminal o que ese sujeto puede actuar con distintas motivaciones. Así, por ejemplo, como lo señalan ROBERT CRYER, HÅKAN FRIMAN, DARRYL 
ROBINSON \& ELIZABETH WILMSHURST, An Introduction to International Criminal Law..., 374 (2014), un traficante, que a sabiendas proporciona armas a un régimen que cometerá crímenes de lesa humanidad con ellas, no sería responsable como cómplice, debido a que su propósito (principal) no es el de apoyar las acciones de dicho régimen, sino obtener provecho económico. De todas maneras, el artículo 25 (3) (d) ER abarcaría estas situaciones, al respecto también STEFANIE BOCK, Zurechnung im Völkerstrafrecht, 410-427, 424 (2017).

109 Sobre la distinción entre derecho penal de acto (Tatstrafrecht) y de autor (Täterstrafrecht), CLAUS ROXIN, Strafrecht Allgemeiner Teil, Band I: Grundlagen. Der Aufbau der Verbrechenslehre, 178-179 (C. H. Beck, München, 2006).

110 En este sentido, HANS VEST, Business Leaders and the Modes of..., 851-872, 871 (2010).

111 INTERNATIONAL COMMISSION OF JURISTS, ICJ, Report of the International Commission of Jurists, Expert Legal Panel on Corporate Complicity in International Crimes, Corporate Criminality \& Legal Accountability Vol. 2: Criminal Law and International Crimes, 32, 34 (International Commission of Jurists, ICJ, Geneva, 2008). Disponible en: http://www.ref world.org/pdfid/4a78423f2.pdf. HANS VEST, Business Leaders and the Modes of..., 851-872, 869 (2010).

112 Al respecto, BORIS BURGHARDT, Die Vorgesetztenverantwortlichkeit im völkerrechtlichen Straftatsystem, 108 ss. (Berliner Wissenschafts-Verlag, Berlin, 2008). KAI AMBOS, Treatise on International Criminal Law, Volume I, 210 ss. (2013).

113 En este sentido, International Criminal Court, ICC, Prosecutor v. Jean-Pierre Bemba Gombo (ICC-01/05-01/08), PTC II, Decision Pursuant to Article 61(7)(a) and (b) of the Rome Statute, 15 June 2009, par. 425. Disponible en: https://www.icccpi.int/pages/record.aspx?uri=699541. Al respecto, KAI AMBOS, Treatise on International Criminal Law, Volume I, 215-217 (2013), sobre la responsabilidad de superiores no militares en el ER (artículo 28 (b) ER), OTTO TRIFFTERER \& ROBERTA ARNOLD, Article 28, Responsibility of Commanders and Other Superiors..., 1101-1103 (2016).

114 NORA KARSTEN, Distinguishing Military and Non-Military Superiors: Reflections on the Bemba Case at the ICC, 7 Journal of International Criminal Justice, 5, 983-1004, 998-1000 (2009). HANS VEST, Völkerrechtsverbrecher verfolgen..., 256-259 (2011).

115 UNICTR, Prosecutor v. Alfred Musema (Case No. ICTR-96-13-A)..., 27 January 2000, par. 131. Sobre "aprobación tácita" como forma de complicidad, ICTY, Prosecutor $v$. Karadžić (Case No. IT-95-5/18-T)..., par. 575; aclarando que, cuando un superior está en presencia de los hechos y su inacción constituye una forma de alentar o incentivar la comisión del crimen, la responsabilidad penal a título de complicidad no se fundamenta en estricto sentido en una omisión, ICTY, Prosecutor v. Brdanin (Case No. IT-99-36-A), Appeals Chamber, AC, Judgement, 3 April 2007, par. 277 ss. Disponible en: http://www.icty.org/x/ca ses/brdanin/acjug/en/brd-aj070403-e.pdf

116 Con relación a este estándar, KAI AMBOS, Treatise on International Criminal Law, Volume I, 227 (2013) ("a new standard [...] close to 'wilfully blind' criterion [...] Wilful blindness, thus, stands between knowledge and recklessness"). CHANTAL MELONI, Command Responsibility. Mode of Liability for the Crimes of Subordinates or Separate Offence of the Superior?, 5 Journal of International Criminal Justice, 3, 619-637, 634-635 (2007).

117 Sobre este estándar como negligencia, KAI AMBOS, Treatise on International Criminal Law, Volume I, 221 (2013). ROBERT CRYER, HÅKAN FRIMAN, DARRYL ROBINSON \& ELIZABETH WILMSHURST, An Introduction to International Criminal Law..., 388-390 (2014). GERHARD WERLE \& FLORIAN JESSBERGER, Völkerstrafrecht, 288-290 (Mohr Siebeck, Tübingen, 2016).

118 Sobre los problemas de esta forma de responsabilidad a la luz del principio de culpabilidad, KAI AMBOS, Treatise on International Criminal Law, Volume I, 230-231 (2013).

119 Sobre complicidad por omisión, ICTY, Prosecutor v. Mrkšić et al. (Case No. IT-95-13/1-A), Appeals Chamber, AC, Judgement, 5 May 2009, par. 49, 82. Disponible en: http://www.icty.org/x/cases/mrksic/acjug/en/090505.pdf

120 Sobre complicidad por omisión en DPI, MILES JACKSON, Complicity in International Law, 98-110 (Oxford University Press, Oxford, 2015).

121 Ver nota 23.

122 Según el Acto Legislativo 02 de 2017, del 11 de mayo, los contenidos del Acuerdo de Paz "serán obligatoriamente parámetros de interpretación y referente de desarrollo y validez de las normas y las leyes” que lo implementen. La Corte Constitucional declaró que este AL se ajustaba a la Constitución. COLOMBIA, CORTE CONSTITUCIONAL, comunicado de prensa No. 51 , 11 de 
octubre de 2017, expediente RPZ-005. Disponible en: http://www.corteconstitucional.gov.co/comunicados/No.\%2051\%20co municado\%2011\%20de\%20octubre\%20de\%202017.pdf

123 Ver notas 14 y 15 , así como el texto principal al cual estas pertenecen.

124 Esto tendrían que definirlo la Sala de Reconocimiento de Verdad o la Sala de Definición de Situaciones Jurídicas, las cuales son los órganos que recibirán los casos antes de que cada persona tenga la oportunidad de reconocer o no si tuvo responsabilidad en la perpetración de crímenes graves. Una vez esto haya sucedido y se haya resuelto sobre la competencia de la JEP, el caso debe pasar al Tribunal de Paz. Acuerdo Final, 154-155 (apartado 5.1.2., punto 48, lit. a., b., c. y e.) y 158 (apartado 5.1.2., punto 50, lit. a., d. y f.).

125 Esto debería tener lugar bien sea ante la Sección del Tribunal para la Paz encargada de dictar sentencias en casos de reconocimiento de responsabilidad o, en caso contrario, ante la Sección encargada de adelantar los juicios. Ibíd., 160 (apartado 5.1.2., punto 52).

126 Este es el criterio aceptado en Colombia para diferenciar entre autoría y participación. ALBERTO SUÁREZ-SÁNCHEZ, Autoria, 213-269 (Universidad Externado de Colombia, Bogotá, 2007).

127 Es decir, la contribución debe influir en la forma como se comete el crimen, o sea, facilitar la comisión, pero no debe constituir una condición necesaria del resultado, HANS VEST, Business Leaders and the Modes of..., 851-872, 857 (2010). ICTY, Prosecutor v. Tadic (Case No. IT-94-1-T), Trial Chamber, TC, Opinion and Judgement, 7 May 1997, par. 689. Disponible en: http://www .icty.org/x/cases/tadic/tjug/en/tad-tsj70507JT2-e.pdf: ("a direct and substantial effect on the commission of the illegal act").

128 Esto también, de forma equivocada, se menciona en el Acuerdo de Paz como condición de la competencia de la JEP, ver nota 23 .

129 Sobre todo, debido a la expresión "atendiendo la importancia del aporte" incluida en el segundo inciso del artículo 29 del Código Penal, que prevé la coautoría. Al respecto, ALBERTO HERNÁNDEZ-ESQUIVEL, Autoría y participación, en Lecciones de derecho penal, Parte general, 267-306, 286-292 y 299-300 (Universidad Externado de Colombia, Bogotá, 2011). FEDERICO LONDONO-MESA, Concurso de personas en la conducta punible, en Derecho penal. Parte general - Fundamentos, 547-590, 574-575 (LEONARDO DAVID LÓPEZ-ESCOBAR, ed., Universidad de Medellín, Medellín, 2011).

130 En este sentido, ALBERTO HERNÁNDEZ-ESQUIVEL, Autoria y participación..., 267-306, 299-300 (2011). Sobre la distinción entre complicidad necesaria y no necesaria, FERNANDO VELÁSQUEZ-VELÁSQUEZ, Manual de derecho penal. Parte general, 583-587 (Ediciones Jurídicas Andrés Morales, Bogotá, 2014). JUAN FERNÁNDEZ-CARRASQUILLA, Derecho penal, Parte general, Vol. 2, Dispositivos amplificadores, concursos y pena, 889-896 (Editorial Ibáñez, Bogotá, 2012).

131 También sería más amplio que en la jurisprudencia de los tribunales ad hoc, aunque no ocurriría lo mismo (nuevamente, en principio) frente al ER. Al respecto, nota 102.

132 En este sentido, en sentencia del 18 de mayo de 2016 [radicado 41758, citada en Colombia, Corte Suprema de Justicia, CSJ, Sala de Casación Penal, sentencia del 8 de febrero de 2017, radicado 46099, 35], la CSJ ha afirmado que la complicidad requiere "la existencia de un vínculo o nexo de causalidad necesario entre la acción desplegada por quien fue acusado como cómplice y el resultado producido por la acción principal ejecutada por los coautores". Sin embargo, en esta misma decisión sostuvo la CSJ que esto "se traduce en la acreditación de que la persona [ha] contribuido elevando la posibilidad de producción del hecho antijurídico”, ibíd., 35. En este mismo sentido, en la decisión del 8 de febrero de 2017, la CSJ dice: "la complicidad [...] debe representar [...] un incremento del riesgo", ibíd., 36 (cursivas por fuera del texto original). Aunque, se debe advertir, aumentar el riesgo de la producción de un resultado no es lo mismo que realizar un aporte indispensable ("necesario") dirigido a este mismo fin. Por otro lado, la CSJ también ha dicho en otras ocasiones, que el cómplice "solo contribuye de manera más o menos eficaz" a la producción del resultado criminal. CSJ, Sala de Casación Penal, sentencia del 15 de marzo de 2017, radicado 48544, 15. CSJ, Sala de Casación Penal, sentencia del 26 de febrero de 2014, radicado 42428, 8, ante lo cual se debe decir, que no es claro si para la CSJ este constituye un criterio distinto al de "nexo de causalidad necesario" o al de "incremento del riesgo". Sobre la aplicación de la teoría del aumento del riesgo en la complicidad, FERNANDO VELÁSQUEZ-VELÁSQUEZ, Manual de derecho penal. Parte general, 593 (2014). JUAN FERNÁNDEZ-CARRASQUILLA, Derecho penal, Parte general, Vol. 2, 901 (Editorial Ibáñez, Bogotá, 2012).

133 Ver nota 102.

$134 \mathrm{Al}$ respecto, notas 106 y 108. 
135 CSJ, Sala de Casación Penal, sentencia del 15 de mayo de 2013, radicado 34320, consideración 7. CSJ, Sala de Casación Penal, sentencia del 25 de abril de 2007, radicado 26617, 27-28.

136 Para la CSJ, el cómplice debe conocer la "naturaleza delictuosa" del hecho y debe haber acordado con el autor "su particular intervención en el mismo”. CSJ, Sala de Casación Penal, sentencia del 8 de febrero de 2017, radicado 46099, 31.

137 Por ejemplo, en un caso de peculado, en el que una persona facilitó cambiar un cheque con dineros producto de la defraudación a un municipio, la CSJ negó la complicidad, a pesar de que el acusado realizó un aporte relevante y podía saber que estaba haciendo algo indebido, entre otras razones, porque este "desconocía los pormenores" sobre la procedencia del dinero. Por esto, la CSJ afirmó que "la colaboración no fue dolosa de peculado". CSJ, Sala de Casación Penal, sentencia del 9 de noviembre de 2016, radicado 44940, 75 .

138 Por ejemplo, FERNANDO VELÁSQUEZ-VELÁSQUEZ, Manual de derecho penal. Parte general, 590, 594 (2014) (sin explicar, sin embargo, cómo se concreta el "doble dolo" en la complicidad). JUAN FERNÁNDEZ-CARRASQUILLA, Derecho penal, Parte general, Vol. 2..., 903 (2012) (aunque de forma algo contradictoria este autor se refiere, por un lado, a una "verdadera convergencia intencional y una real armonía de fines" entre autores y partícipes, mientras que acepta, por otro lado, que el dolo no debe ser producto "en todos los casos" de un acuerdo común y que, de hecho, es procedente el dolo eventual). ALBERTO HERNÁNDEZ-ESQUIVEL, Autoría y participación..., 267-306, 299 (2011), ("el cómplice debe conocer que está contribuyendo a la realización de una conducta punible"). Al contrario, siguiendo un enfoque más estricto, similar al de la CSJ, FEDERICO LONDOÑO-MESA, Concurso de personas en la conducta punible..., 547-590, 579 (2011) ("acuerdo [...] donde se deje clara la labor que cada uno de ellos deberá desempeñar”).

139 En este sentido, CLAUS ROXIN, Strafrecht Allgemeiner Teil, Band II: Besondere Erscheinungsformen der Straftat, 224-225 (C. H. Beck, München, 2003): “Doppelvorsatz des Gehilfe”. UWE MURMANN, Grundkurs Strafrecht..., 368 (2015): "der (zumindest bedingte) Vorsatz [muss sich] sowohl auf die Unterstützungshandlung als auch auf die Haupttat beziehen". REINHART MAURACH, KARL GÖSSEL \& HEINZ ZIPF, Strafrecht Allgemeiner Teil, Teilband 2: Erscheinungsformen des Verbrechens und Rechtsfolgen der Tat, 598 (C. F. Müller, Heidelberg, 2014): "[d]olus eventualis genügt".

140 CLAUS ROXIN, Strafrecht Allgemeiner Teil..., 225 y pie de página 369 (2003). UWE MURMANN, Grundkurs Strafrecht..., 369 (2015): "[b] ei der Beihilfe sollen die Anforderungen an die Bestimmtheit des Vorsatzes aber geringer sein als beim Anstifter”. REINHART MAURACH, KARL GÖSSEL \& HEINZ ZIPF, Strafrecht Allgemeiner Teil..., 599-601 (2014): “[d]er Gehilfe muss also weder Tatort noch Tatzeit, ja nicht einmal die Person des Haupttäters kennen".

141 En este sentido, con relación al DPI, HANS VEST, Business Leaders and the Modes of..., 851-872, 871-872 (2010). La responsabilidad penal a título de comisión por omisión (artículo 25 Código Penal) hace las veces, en el ámbito nacional, de equivalente (al menos parcial) de la figura (internacional) de responsabilidad del superior jerárquico. En este sentido, con relación a superiores militares, GUSTAVO COTE-BARCO, Responsabilidad del superior jerárquico y responsabilidad penal por omisión de miembros de la Fuerza Pública en Colombia: ¿convergencia entre el derecho penal nacional e internacional?, 28 International Law, Revista Colombiana de Derecho Internacional, 49-112, 88-97 (2016).

142 FERNANDO VELÁSQUEZ-VELÁSQUEZ, Manual de derecho penal. Parte general, 595 (2014). FEDERICO LONDOÑO-MESA, Concurso de personas en la conducta punible..., 547-590, 574-575, 577-578 (2011).

143 Según el primer inciso del artículo 340 del Código Penal: "Cuando varias personas se concierten con el fin de cometer delitos, cada una de ellas será penada, por esa sola conducta, con prisión de cuarenta y ocho (48) a ciento ocho (108) meses” (cursivas por fuera del texto original).

144 Según el segundo inciso del artículo 340 del Código Penal, "la pena será de prisión de ocho (8) a dieciocho (18) años [...]", cuando el concierto sea para cometer los siguientes delitos: genocidio, desaparición forzada de personas, tortura, desplazamiento forzado, homicidio, terrorismo, tráfico de drogas tóxicas, estupefacientes o sustancias sicotrópicas, secuestro, secuestro extorsivo, extorsión, enriquecimiento ilícito, lavado de activos o testaferrato y conexos, o financiamiento del terrorismo y administración de recursos relacionados con actividades terroristas.

145 COLOMBIA, FISCALÍA GENERAL DE LA NACIÓN, FGN, Financiación de empresas bananeras a grupos paramilitares es delito de lesa humanidad, 2 de febrero de 2017. Disponible en: https://www.fiscalia.gov.co/colombia/noticias/fin anciacion-de-empresas-bananeras-a-grupos-paramilitares-es-delito-de-lesa-humanidad/. COLOMBIA, FISCALÍA GENERAL DE LA NACIÓN, FGN, Dirección de Fiscalía Nacional Especializada de Justicia Transicional, Resolución Interlocutoria No. 002, Medellín (Antioquia), 12 de diciembre de 2016. Disponible en: http://www.derechos.org/nizkor/colombia/doc/accu1.ht $\mathrm{ml}$ \#conc 
146 CSJ, Sala de Casación Penal, sentencia del 10 de abril de 2008, radicado 29472, consideración 25. CSJ, Sala de Casación Penal, sentencia del 21 de septiembre de 2009, radicado 32022, 222-223. CSJ, Sala de Casación Penal, sentencia del 7 de noviembre de 2012, radicado 39665, 21-22.

147 COLOMBIA, FISCALÍA GENERAL DE LA NACIÓN, FGN, Financiación de empresas bananeras a grupos paramilitares...: "En la providencia que emite la Fiscalía se decide que la conducta en la que pudieron incurrir algunos empresarios del banano puede elevarse a la categoría de crimen de lesa humanidad, lo que la ubicaría en el plano de la imprescriptibilidad”.

148 CSJ, Sala de Casación Penal, decisión del 24 de julio de 2017, radicado 50458, 9. CSJ, Sala de Casación Penal, decisión del 16 de agosto de 2017, radicado 50458, 2. CSJ, Sala de Casación Penal, decisión del 24 de julio de 2017, radicado $49253,18$.

149 COLOMBIA, FISCALÍA GENERAL DE LA NACIÓN, FGN, Dirección de Fiscalía Nacional Especializada de Justicia Transicional, Resolución Interlocutoria No. 002, Medellín (Antioquia), 12 de diciembre de 2016: "el delito de concierto para delinquir es imprescriptible [...] por constituirse en un acto preparatorio de los crímenes de lesa humanidad".

150 Artículos 3 y 5 Estatuto del TPIY y artículo 7 ER.

151 Según el artículo 7 (1) (k) ER, también constituyen crímenes de lesa humanidad “[o] tros actos inhumanos de carácter similar que causen intencionalmente grandes sufrimientos o atenten gravemente contra la integridad física o la salud mental o física”.

152 ICTY, Prosecutor v. Tadić (Case No. IT-94-1-A)..., par. 220, 227.

153 Por ejemplo, GEORGE P. FLETCHER \& JENS DAVID OHLIN, Reclaiming Fundamental Principles of Criminal Law in the Darfur Case, 3 Journal of International Criminal Justice, 539-561, 548-550 (2005). Al respecto, también, KAI AMBOS, Treatise on International Criminal Law, Volume I, 160-163, 172-176 (2013).

154 Ver nota 107.

155 Según el artículo 9 del Estatuto del TPM de Núremberg, el Tribunal podía declarar ciertas organizaciones como criminales; sobre esta base, en procesos subsiguientes era posible declarar penalmente responsables a personas que hubieran sido miembros de estas organizaciones por ese solo hecho, tal como lo preveía el artículo II (1) (d) de la Ley 10 del Consejo de Control Aliado. Al respecto, STEFANIE BOCK, Zurechnung im Völkerstrafrecht, 410-427, 414-415, 416-417 (2017) (sobre las diferencias entre la penalización de la pertenencia a un grupo y la empresa criminal conjunta, ECC).

156 Así, con relación al artículo 9 de su Estatuto, el TPM de Núremberg afirmó: "that definition should exclude persons who had no knowledge of the criminal purposes or acts of the organization and those who were drafted by the State for membership, unless they were personally implicated in the commission of acts declared criminal by Article 6 of the Charter as members of the organization. Membership alone is not enough to come within the scope of these declarations", TPM (nota 31 ), 256.

157 Acuerdo Final, 151 (apartado 5.1.2., punto 40). Esta lista aparece también en los artículos 23 (parágrafo, lit. a.), 30 y 46 (1) de la Ley 1820 de 2016; ver nota 23.

158 Acuerdo Final, 158-159 (apartado 5.1.2., punto 50 lit. f).

\section{Licencia Creative Commons CC BY 4.0}

Para citar este articulo / To cite this article: COTE-BARCO, GUSTAVO EMILIO, Complicidad, responsabilidad penal de directivos empresariales y violaciones de Derechos Humanos cometidas por grupos armados ilegales: lecciones del Derecho Penal Internacional para Colombia, 138 Vniversitas (2019). https://d oi.org/10.11144/Javeriana.vj138.crpd 